\title{
A Methodical Review on the Applications and Potentialities of Using Nanobiosensors for Disease Diagnosis
}

\author{
Kingsley Eghonghon Ukhurebor $\mathbb{D D}^{1}$ Robert Birundu Onyancha $\mathbb{D}^{1},{ }^{2}$ Uyiosa Osagie Aigbe $\mathbb{D}^{2},^{3}$ \\ Gladys UK-Eghonghon, ${ }^{4}$ Rout George Kerry $\mathbb{D}^{5}{ }^{5}$ Heri Septya Kusuma $\mathbb{D}^{\circ}{ }^{6}$ \\ Handoko Darmokoesoemo, ${ }^{7}$ Otolorin Adelaja Osibote $\mathbb{D}^{3}{ }^{3}$ \\ and Vincent Aizebeoje Balogun $\mathbb{D}^{8}$
}

${ }^{1}$ Department of Physics, Faculty of Science, Edo State University Uzairue, P.M.B. 04, Auchi, 312101 Edo State, Nigeria

${ }^{2}$ Department of Physics and Space Science, School of Physical Sciences and Technology, Technical University of Kenya, P.O. Box 52428, 00200 Nairobi, Kenya

${ }^{3}$ Department of Mathematics and Physics, Faculty of Applied Sciences, Cape Peninsula University of Technology, P.O. Box 1906, Cape Town, South Africa

${ }^{4}$ Nursing Services Department, University of Benin Teaching Hospital, P.M.B. 1111, Benin City, Nigeria

${ }^{5}$ Department of Biotechnology, Utkal University, Vani Vihar, Bhubaneswar, Odisha 751004, India

${ }^{6}$ Department of Chemical Engineering, Faculty of Industrial Technology, Universitas Pembangunan Nasional "Veteran", Yogyakarta, Indonesia

${ }^{7}$ Department of Chemistry, Faculty of Science and Technology, Airlangga University, Mulyorejo, Surabaya 60115, Indonesia

${ }^{8}$ Department of Mechanical Engineering, Faculty of Engineering, Edo State University Uzairue, P.M.B. 04, Auchi,

312101 Edo State, Nigeria

Correspondence should be addressed to Robert Birundu Onyancha; 08muma@gmail.com

Received 21 July 2021; Revised 23 October 2021; Accepted 8 January 2022; Published 29 January 2022

Academic Editor: Martín F. Desimone

Copyright (c) 2022 Kingsley Eghonghon Ukhurebor et al. This is an open access article distributed under the Creative Commons Attribution License, which permits unrestricted use, distribution, and reproduction in any medium, provided the original work is properly cited.

Presently, with the introduction of nanotechnology, the evolutions and applications of biosensors and/or nanobiosensors are becoming prevalent in various scientific domains such as environmental and agricultural sciences as well as biomedical, clinical, and healthcare sciences. Trends in these aspects have led to the discovery of various biosensors/nanobiosensors with their tremendous benefits to mankind. The characteristics of the various biosensors/nanobiosensors are primarily based on the nature of nanomaterials/nanoparticles employed in the sensing mechanisms. In the last few years, the identification, as well as the detection of biological markers linked with any form of diseases (communicable or noncommunicable), has been accomplished by several sensing procedures using nanotechnology vis-à-vis biosensors/nanobiosensors. Hence, this study employs a systematic approach in reviewing some contemporary developed exceedingly sensitive nanobiosensors alongside their biomedical, clinical, or/and healthcare applications as well as their potentialities, specifically for the detection of some deadly diseases drawn from some of the recent publications. Ways forward in the form of future trends that will advance creative innovations of the potentialities of nanobiosensors for biomedical, clinical, or/and healthcare applications particularly for disease diagnosis are also highlighted. 


\section{Introduction}

The detecting of any disease (known as diagnosis in the medical terms) be it communicable (which result in about 4 million deaths annually around the world) or noncommunicable (causing over $70.00 \%$ of all deaths globally) is one of the dominant aspects toward the improvement of the efficiency of any biomedical/clinical/healthcare process [1-4]. According to the World Health Organization (WHO), the basic human diseases and infections are identified with the deficiency in access to good food and clean drinking water; explicitly, the utilization of hazardous water mostly from industrial activities represents about $80.00 \%$ of most diseases [5-7]. Hence, there is a need to continually search for diagnostic remedies to these diseases. Reportedly, the two basic prognoses in biomedical/ clinical/healthcare diagnosis are the confirmation of the disease and the investigation of the vulnerability of an individual's as an age-linked category for several diseases. As rightly reported by the WHO, approximately $17.00 \%$ of every six deaths resulting from cancerous complications as well as other deadly diseases are caused by the latephase detection and remote biomedical/clinical/healthcare diagnosis [8].

The treatment and convalescence for any kind of disease primarily depend on its early-phase detention as well as the effectiveness of the diagnosis processes [8,9]. Microscopic procedures, immunosorbent approaches, and immunofluorescence (FRS) though demonstrated to be clinically critical in dealing with various diseases. However, they tend to exhibit certain limitations such as truncated sensitivity, stumpy-specificity, inaccuracy, expensiveness, and their cumbersome nature [10]. To mitigate these shortcomings, rapid, biocompatible, effective, and excellent throughput analytical procedures are now the evolving biomedical/clin$\mathrm{ical} /$ healthcare necessities.

Historically, the development of nanoparticles (NPs) commenced with the work of Ehrlich before the initial trials by Scheffel et al. as well as the all-embracing research work by some group of senior researchers led by Prof. Speiser at the ETH Zurich toward the end of the 1960s and beginning of the 1970s, with significant devotion to its development in the 1980 s, particularly for medical purposes such as the delivery of drug voyage the blood-brain barrier (3Bs) [11, 12]. Presently, there are several reported categories of NPs, of which their magnitude (that is size and shape), as well as their origin to a large extent, is instrumental to determining their applications. Some of the commonest categories of NPs are shown in Figure 1 with particular reference to the ones used for biomedical purposes as represented in literature [12].

Supposedly, NPs are utilized as a means for delivering loaded constituents via two basic mechanisms: encapsulation (employing lipid-based/polymer-based capsules) and polymer-based components (employing natural/synthetic polymers) [12]. Generally, NPs have numerous benefits as compared to the conventional measures in the diagnostics/ therapeutics fields. According to Jurj et al. [13], they are habitually harmless and biocompatible and can cross the
3Bs as well as other physiological constricts that serve as barriers [14]. Also, they could efficiently destroy intracellular and multiple drug-resistant pathogens [15], and they offer new procedures for the development of vaccines and gene treatments/rehabilitation (therapy) $[16,17]$.

Presently, biosensors (BioSS) are very significant for sensing target particles with great precision, selectivity, and signal-to-noise proportion. BioSS which are technologically advanced using BMs such as enzymes or nucleic acids (DNA/RNA) which are employed as the probes for sensing the target particles are presently been given great attention by several researchers owing to their numerous dynamic advantages. Enzymes that react with definite particles rapidly and selectively as well as the DNA/RNA can combine with their corresponding categorizations precisely in nanoscale [18]. Also, biomolecules (BMs) could immobilize and conjugate with other particles by modifying the surface via the relocation or introduction of chemical linkers $[19,20]$.

Recently, the identification, as well as the detection of biomarker (BioMK) linked with any form of diseases, has been attained by several sensing procedures using nanotechnology (NanoTech) [21]. Some of these procedures comprise of electrodes with high conductivity that could identify or trace electron (particle) dynamic BMs or NPs, which are present in the body specifically for disease situations and for the generation of resilient signals [19]; all these stated characteristics are notable in sensing mechanism known as BioSS. These BioSS are generally characterized based on either the biological constituents (elements)/the category of the receptor that includes enzymes, cells and cell organelles, antibody (AB), or/and affinity receptors (DNA/ RNA probes) and artificial (nonnatural) receptors or on the transducing constituents such as acoustic, calorimetric, electrochemical (ETC), and optical tendencies. BioSS can be characterized by the utilized transduction sensing procedure during its fabrication. The commonest categories and subcategories of BioSS are shown in Figure 2 [8]. However, Figure 3 shows a block pattern of a practical BioSS designed for the detention of diseases, and Figure 4 shows a distinctive diagram of an ETC BioSS.

Consequently, the implementation of BioSS is a beneficial approach for the protuberant detection of biological markers. Furthermore, the recent advancements in BioSS mechanism vis-à-vis nanobiosensor (NanoBioSS) have resulted in evolutionary modifications in various research fields, namely, agricultural, environmental, and biomedical/ clinical/healthcare sciences as well as several other domains of human endeavours [22-28].

Most of the preeminent applications of BioSS/NanoBioSS are found in the diverse manufacturing segments of which the biomedical/clinical/healthcare services are the primary ones $[29,30]$. Figure 5 explores some of the utmost distinctive applications and proficiencies of NanoTech visà-vis BioSS/NanoBioSS that fall within the canopy of the biomedical/clinical/healthcare services as well as the allied services; the figure is a summary of NanoTech utilized for some of the utmost biomedical purposes such as diagnostic, therapeutics, and immunization [12]. 


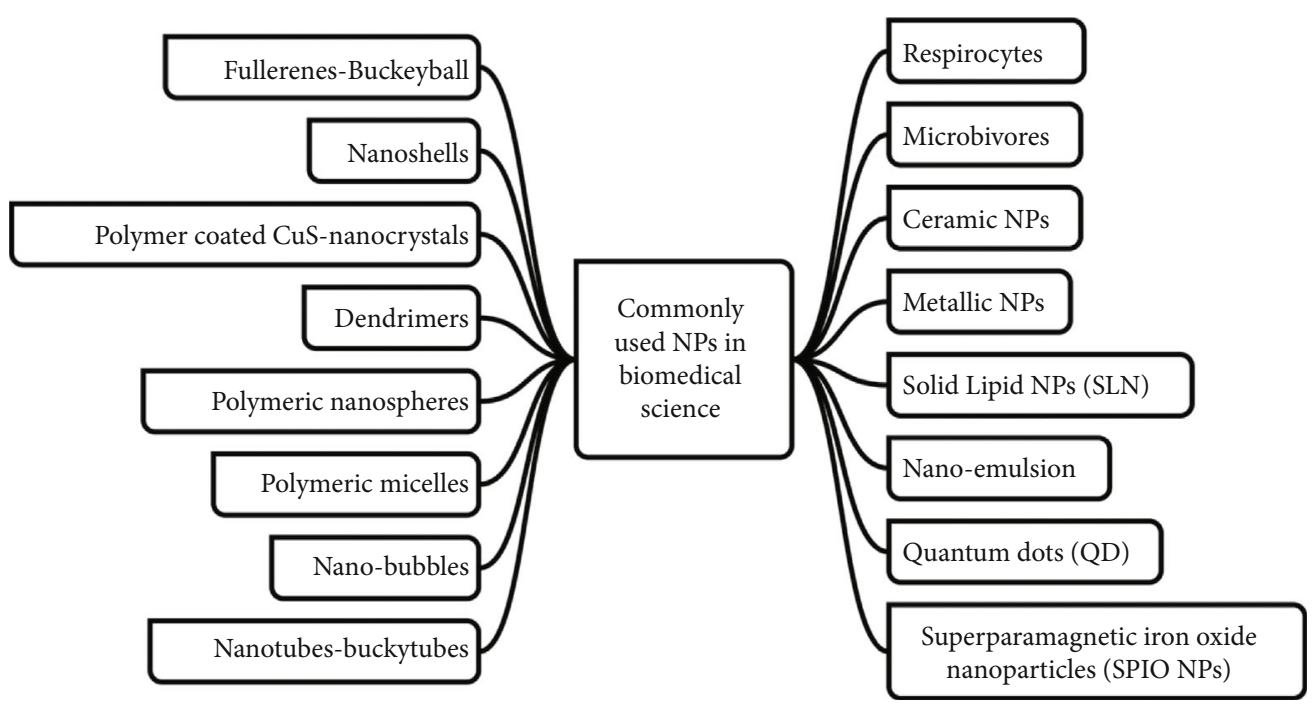

FIGURE 1: Diagrammatic illustration showing some of the commonest categories of NPs used for biomedical purposes [12].

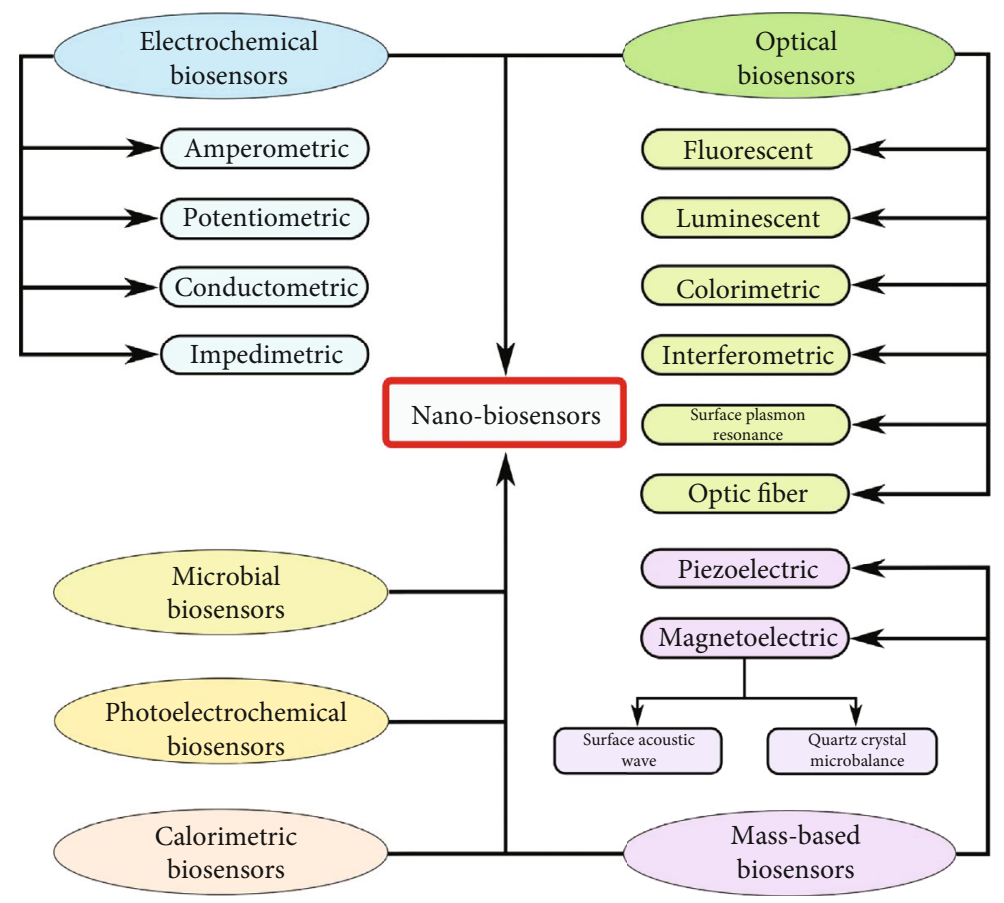

FIGURE 2: Some of the commonest categories and subcategories of BioSS [8].

The detection of diseases, retinal prostheses, cellular miRNA appearance in colorectal cancerous complications, imaging of contrast during MRIs, diagnosis of the heart, medicinal mycology, and the monitoring of health are the main momentous physiognomies or largely characterized areas well served with BioSS/NanoBioSS benefits [31-33]. These all-encompassing applications and proficiencies additionally improve the biomedical/clinical/healthcare services to an innovative pinnacle together with exceptional societal services [34-36].
Diverse irresistible diseases and infections spread such as Ebola, SARS, Hendra, Nipah, Avian influenza, and COVID-19 (SARS-CoV-2) have turned into a global threat that needs extensive exertion in their proliferation to manage. As there are diverse complications related to these irresistible diseases' infections, more advance diagnostic mechanisms need to be developed for mitigation and/or eliminating the odds of infection outbreak beforehand. BioSS/NanoBioSS has stood out as one of the appealing mechanisms for giving influential statistics on these 


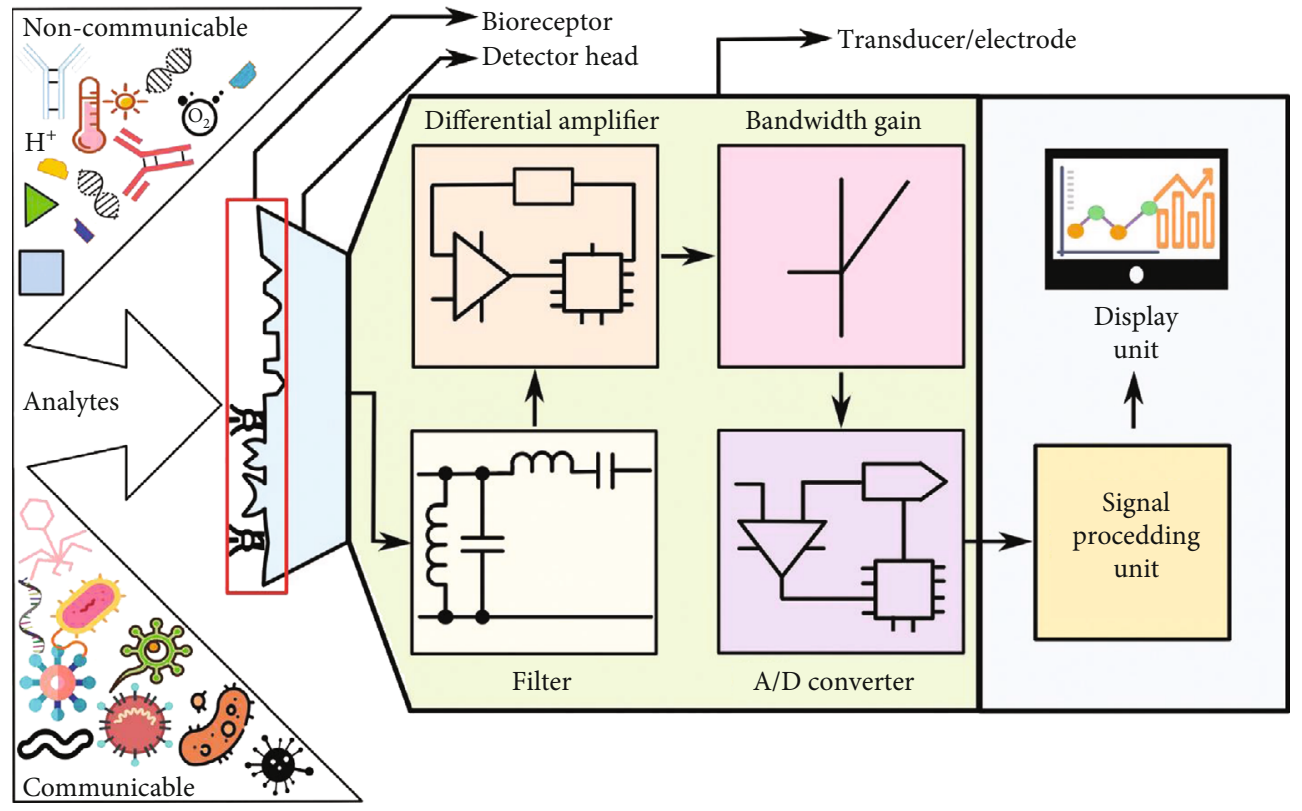

FIgURE 3: A block pattern of a practical BioSS for the detention of diseases [8].

diseases and infections. The recent SARS-CoV-2 plague (pandemic), which is extremely infectious, originated from a recently known coronavirus that has adversely obstructed humanity [37]. There have been some reported research studies on the application of BioSS/NanoBioSS in mitigating this dreaded virus $[35,38-41]$. In the same way, innumerable other communicable and noncommunicable diseases such as Avian influenza, Ebola, Hendra, Nipah, and SARS have spawned substantial interest in recent times. Consequently, BioSS/NanoBioSS have enormous potential and proficiencies in detecting the outbreak of deadly virus together with any other diseases. Another great proficiency of the BioSS/NanoBioSS is in the diagnosis of the heart. Cardiovascular diseases are known as one of the utmost sources of death around the world, resulting in the death of over 17 million annually [2]. BioSS/NanoBioSS using BioMK is playing a critical role in the insurgency of diagnostic cardiovascular illnesses. The design and evolution of exceedingly sensitive and specific BioSS/ NanoBioSS utilizing appropriate surface interactions and nanomaterials (NMs) are crucial for the specific diagnosis of heart illnesses [31-33, 42, 43].

Over the years, several categories and subcategories of BioSS/NanoBioSS have been developed with vast applications (see Figure 2 for some of the main categories and subcategories of BioSS/NanoBioSS). Notwithstanding the effectiveness of most BioSS, there are still some reported limitations such as meagre selectivity, the influence of the charged constituent parts (particles) mostly in the form of interference, deficiency in the surface designs, and vulnerability to some environmental (ecological) interference $[19,44-46]$. But with the evolutions of NanoTech (whose main concept deals with the execution of BMs or NPs, with an operational dimension of below

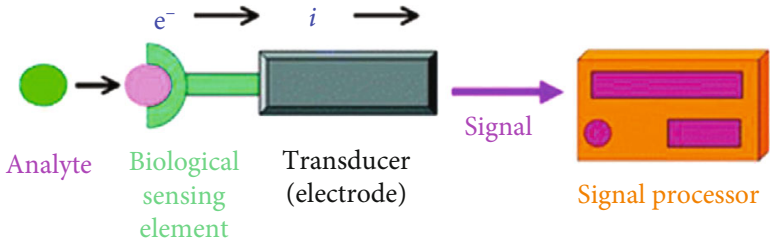

Figure 4: A distinctive diagram of an ETC BioSS [9].

$100 \mathrm{~nm}$, in handling materials at the microscopic level [47]), some of these reported limitations are now been effectively moderated. According to [19], some of these critical limitations of BioSS are a result of variability and truncated signal strength resulting from the detector BMs. Henceforward, functional NMs assist in the mitigation of these limitations of BMs through the hybridization with or substitution of the BMs. Consequently, these functional NMs are beneficial for developing and evolving of the BioSS/NanoBioSS together with the increase of ETC signals, preservation of the actions of BMs for a lengthy duration, and advancement of investigating devices by the utilization of its distinctive plasmonic and optical possessions. Hitherto, numerous NMs have been produced and reported, ranging from broadly used Au NPs to innovative NMs that are either carbon-grounded or transitionmetal dichalcogenide-grounded. These NMs were exploited either by themselves or through the hybridization (mixture) with other NMs for the development of highly sensitive BioSS/NanoBioSS [19]. Figure 6 shows some of the notable historical background and advancements of some of the reported developments for BioSS/NanoBioSS mechanisms as adapted from [8]. 


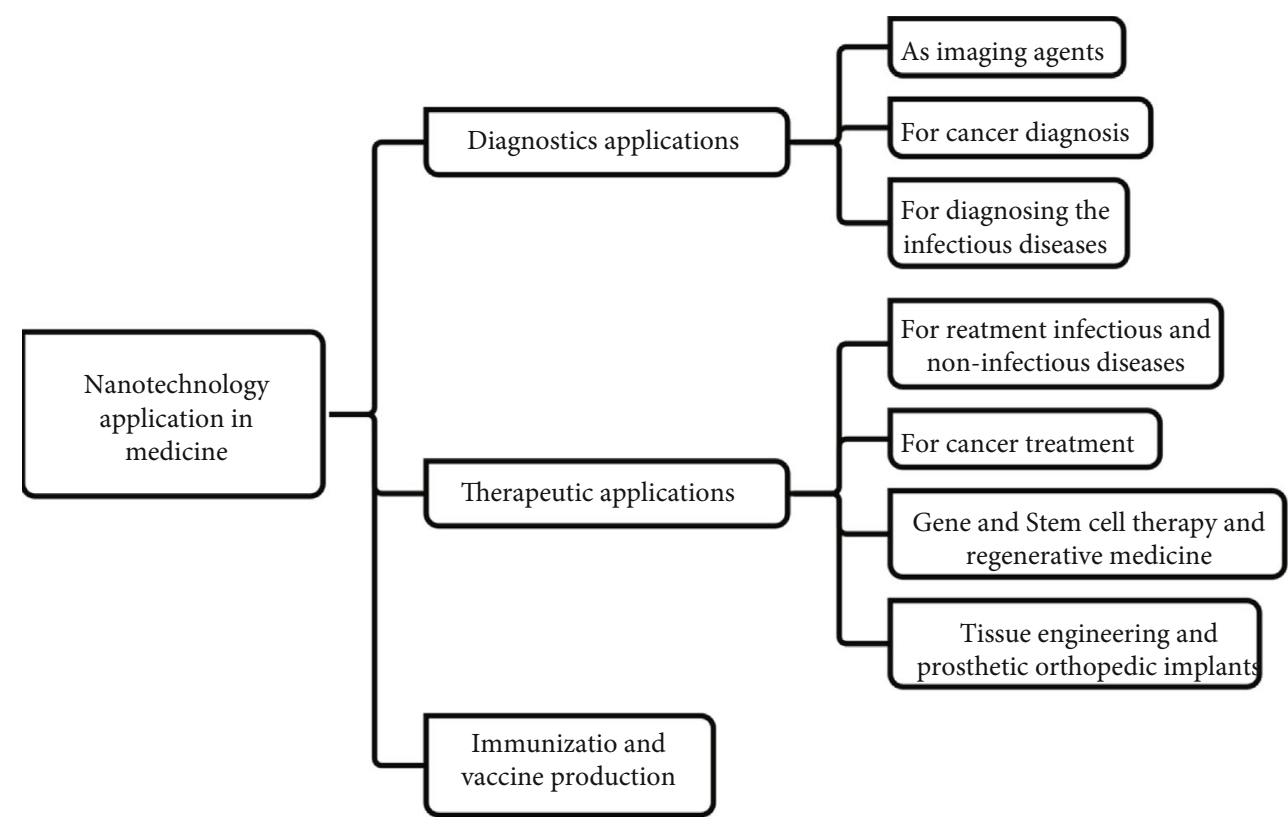

FIGURE 5: Some of the utmost applications of NPs for biomedical purposes [12].

Reportedly, the performance of any BioSS/NanoBioSS is exceptional owing to their remarkable linearity, selectivity, sensitivity, and stability tendencies coupled with their outstanding response time and reproducibility as against the traditional BioSS. This evolving method is censoriously beneficial in the biomedical/clinical/healthcare domain as well as in clinical diagnosis. Hence, this study employs a systematic approach in reviewing some contemporary developed NanoBioSS together with their biomedical/clinical/ healthcare applications and potentialities, specifically for the detection of some deadly diseases drawn from some of the recent publications. The study concludes by suggesting the way forward in the form of future trends that will advance creative innovations of the potentialities of nanobiosensors for biomedical, clinical, or/and healthcare applications particularly for disease diagnosis.

\section{NanoTech in BioSS/NanoBioSS Mechanisms}

BioSS/NanoBioSS are analytical devices that possess a biological sensor in addition to a physicochemical converter $[22,23,28]$. One of the major functions of any BioSS/ NanoBioSS is to provide an incessant digital electrical signal that is comparative proportional to the summation of one or more ingredients that are being analysed [22].

BioSS/NanoBioSS are aiding some of the key advances in the analytics domains that are both assisting and being assisted by advances in NanoTech, implying that they represent both facilitating machinery and evolving applications in diverse fields. The capability of these BioSS/ NanoBioSS to swiftly and precisely detect a substantial amount of NMs makes them vastly pertinent to a range of industrial, agricultural, ecological, and biomedical/clini$\mathrm{cal} /$ healthcare as well as other scientific applications. Proce- dures to BioSS/NanoBioSS design/fabrication are as diverse as their applications, of which each of these BioSS/NanoBioSS categories has advantages and restrictions in the form of limitations based on the anticipated application, as well as the parameters that are essential for their optimum performance [23]. Hence, to be specific, the choice of BioSS/NanoBioSS design/fabrication should ruminate factors, for example, the sensitivity, specificity, dynamic range, output mode, activation time, usage simplicity, and engineering simplicity.

At the moment, BioSS/NanoBioSS are used in several aspects of human endeavours such as diagnosing different diseases and monitoring and management of the quality food and environmental effluences [8, 25, 28, 48, 49]. The surface dimension ratio of most frequently used NMs in BioSS/NanoBioSS such as noble metal NPs, quantum dot (QD), carbon-based NMs, and other NMs is larger when compared to the bulk arrangement of the material and this makes their properties (chemical, electrical, and optical) different and better enhanced [50]. These enhanced properties of NMs offer quicker detection and advanced reproducibility in NanoBioSs. Hence, NMs provide enhanced efficiency BioSS/NanoBioSS by improving the properties (ETC, mechanical and magnetic, and optical) of BioSS/ NanoBioSS [51]. The fact that BioSS are more sensitive and compact today is achieved by including NMs in these bioanalytical devices.

For example, an innovative $3^{\text {rd }}$-generation glucose BioSS based on distinctive hollow PtNPs decorated with multiwalled CN (PtNPs-NT) composites was effectively fabricated. The PtNPs-NT composites were effectively arranged and directly cast on the glassy carbon electrode (GCE) surface. With the aid of electrostatic adsorption and covalent bonding, the negative (-) 1-cysteine (1-cys) and the positive (+) 


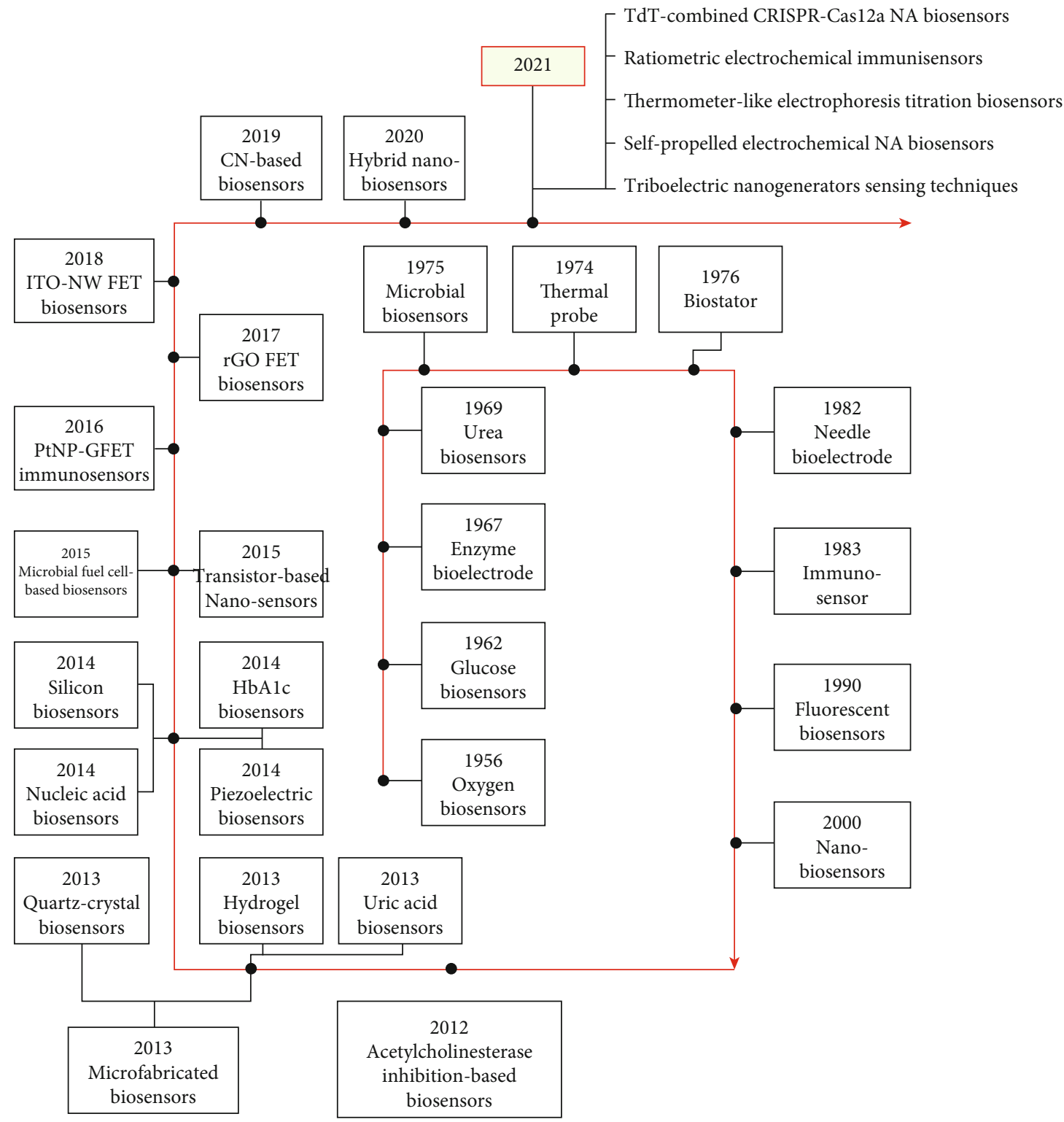

FIGURE 6: Historical background and advancements of some of the developments in BioSS/NanoBioSS [8] (FET: field effect transistor; GP: graphene; PtNP: platinum nanoparticle; rGPO: reduced graphene oxide; ITO-NW: indiumtin oxide nanowires; $\mathrm{CN}=$ : carbon nanotube; TdT: terminal deoxynucleotidyl transferase.

poly (diallyl dimethylammonium) chloride- (PDDA-) coated gold $(\mathrm{Au}) \mathrm{NPs}$ were improved on the ensuing surface of the electrode, which brought additional immobilization of glucose oxidase. Manipulation of the distinctive possessions of PtNPs-NT composites resulting in the accomplishment of direct transfer of electron among the electrode and the redox-active centres of glucose oxidase and the electrode demonstrated a couple of distinct reversible redox peaks with a fast heterogeneous rate of transfer of electrons [52] The images of the TEM representing a solid composite of Pt-supported multiwalled $\mathrm{CN}$ and the hollow composite of Pt-supported multiwalled $\mathrm{CN}$ are shown in Figure 7 [52].
It is proven that $\mathrm{CN}$ has the prospective properties to transform several uses and benefits where nanosized metallic and/or semiconducting mechanisms are necessary [53]. For example, glucose BioSS combined with $\mathrm{CN}$ has been decorated with Au-coated Pd nanotubes [54], Au NPs [55], and Pt NMs [56]. Predominantly, Pt NMs with hollow interiors are auspicious due to their proficiencies to boost electron conveyance and upsurge the surface area. Spreading the surface area of the cathode powder is an active procedure for raising the activity of an electrode [57]. A BioSS on which the multiwalled $\mathrm{CN}$ coated with distinctive hollow nanostructure (NS) Pt has led to the accomplishment of direct transfer of electrons (Figure 8) [9]. 


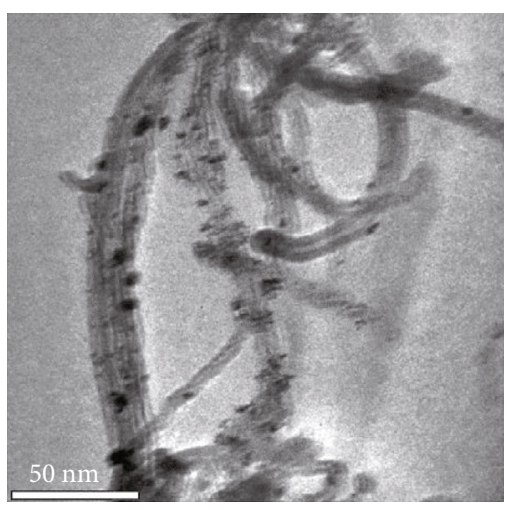

(a)

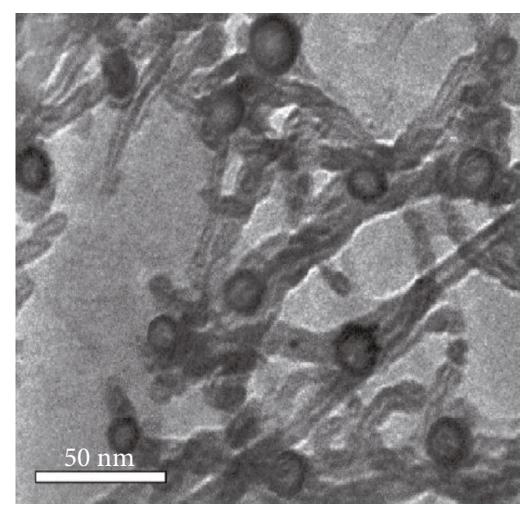

(b)

Figure 7: Images of TEM representing (a) a solid composite of Pt-supported multiwalled CN and (b) hollow composite of Pt-supported multiwalled CN [52].
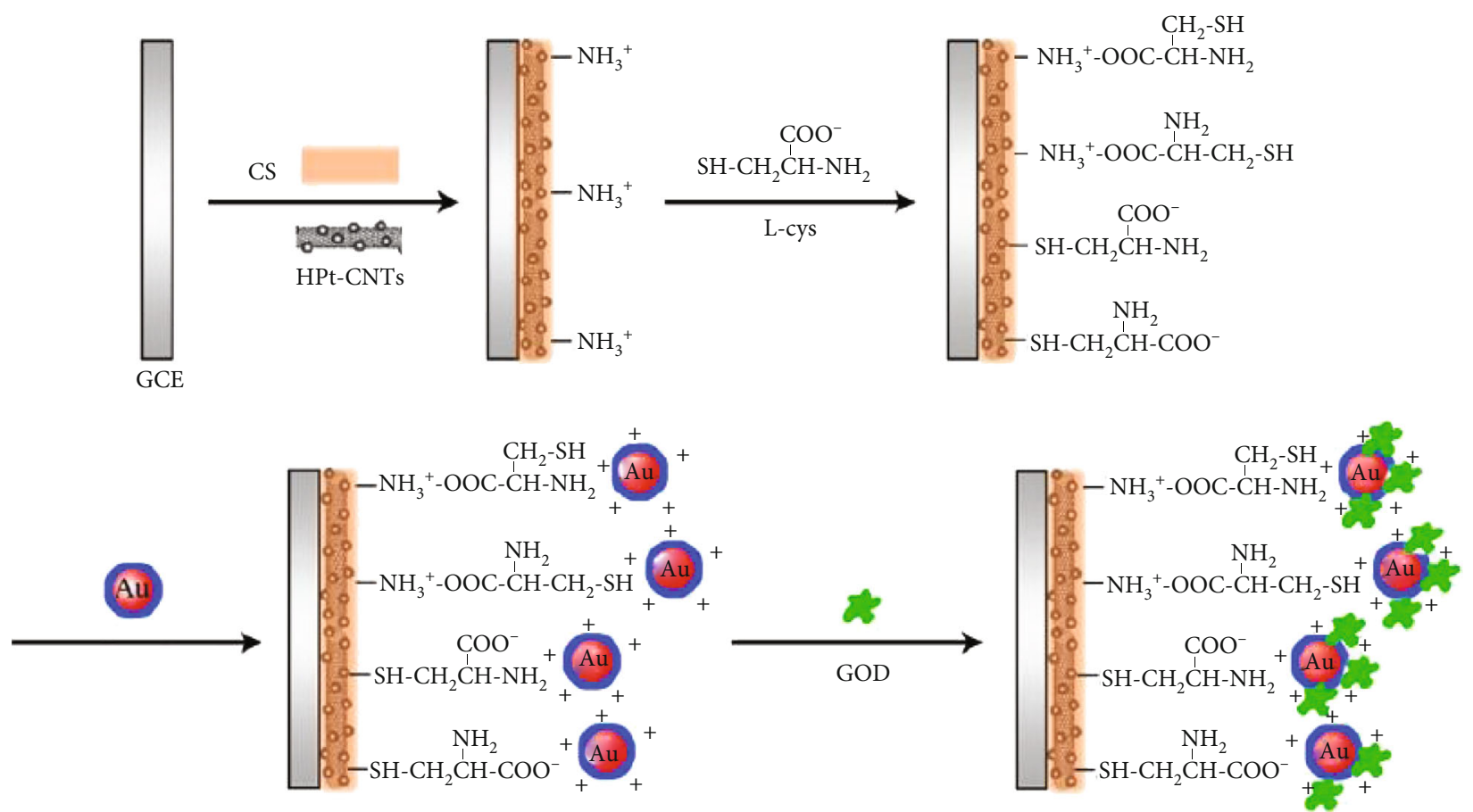

FIgURE 8: An illustrative representation of BioSS (Pt-CN) fabricated from multiwalled CN and hollow PtNPs-NT [52].

Several papers have reported on the uses of NanoTech visà-vis BioSS/NanoBioSS for biomedical/clinical/healthcare applications (such as identifying of viruses and pathogen microbes, detecting of cancerous cells, and breath analysis mechanism) [27, 58], environmental applications (detection of air, soil, and water pollution) [59-61], and agricultural applications (climate-smart organic agriculture and identification of animals and plants pests and diseases) [25, 48, 62-64]. There have also been suggestions on modern materials science vis-à-vis NanoTech been employed in COVID-19-related researches, as this has evidently played a dynamic role in mitigating and combating the present deadly COVID-19 compli- cations via environmental remediation [37]. For example, Figure 9, as adapted from [65], illustrates the basic components, the various routes of transmission, and the duplication cycles of COVID-19 together with the utility of modern materials science in mitigating and combating the COVID-19 pandemic complications.

However, the major concentration of this facile review study is on the biomedical/clinical/healthcare applications of NanoTech vis-à-vis BioSS/NanoBioSS particularly for the detection of some deadly diseases drawn from some of the recent publications and this is being done in the subsequent section. 


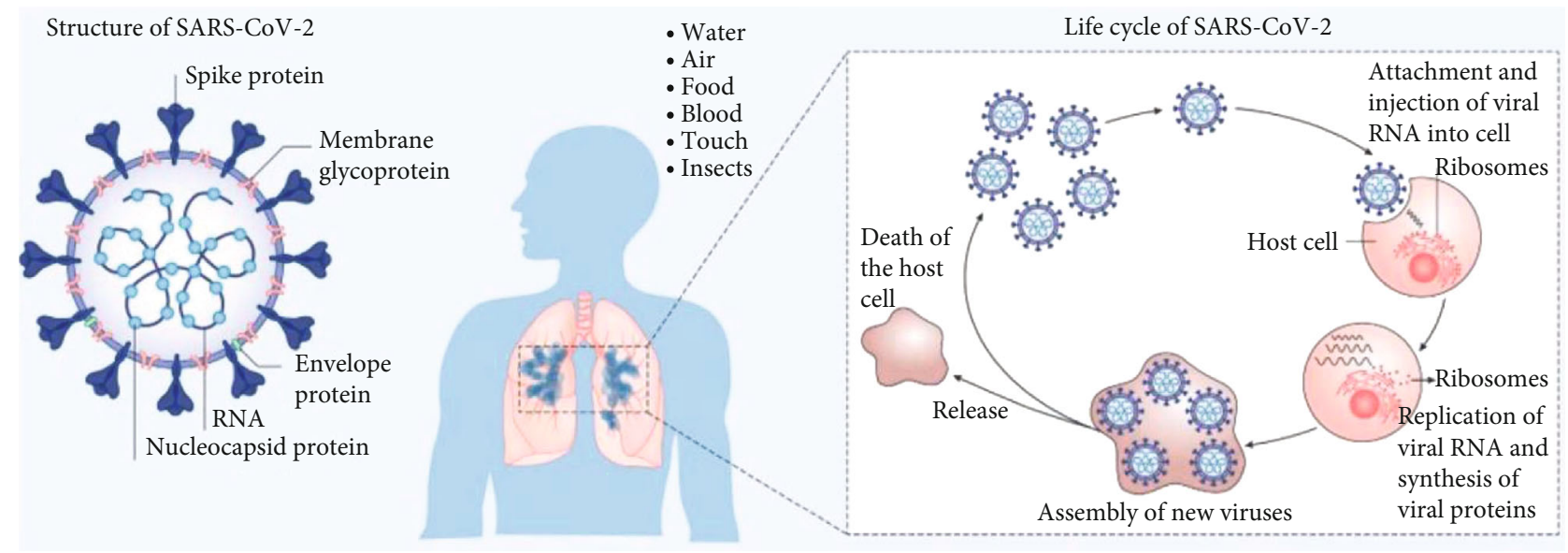

(a)

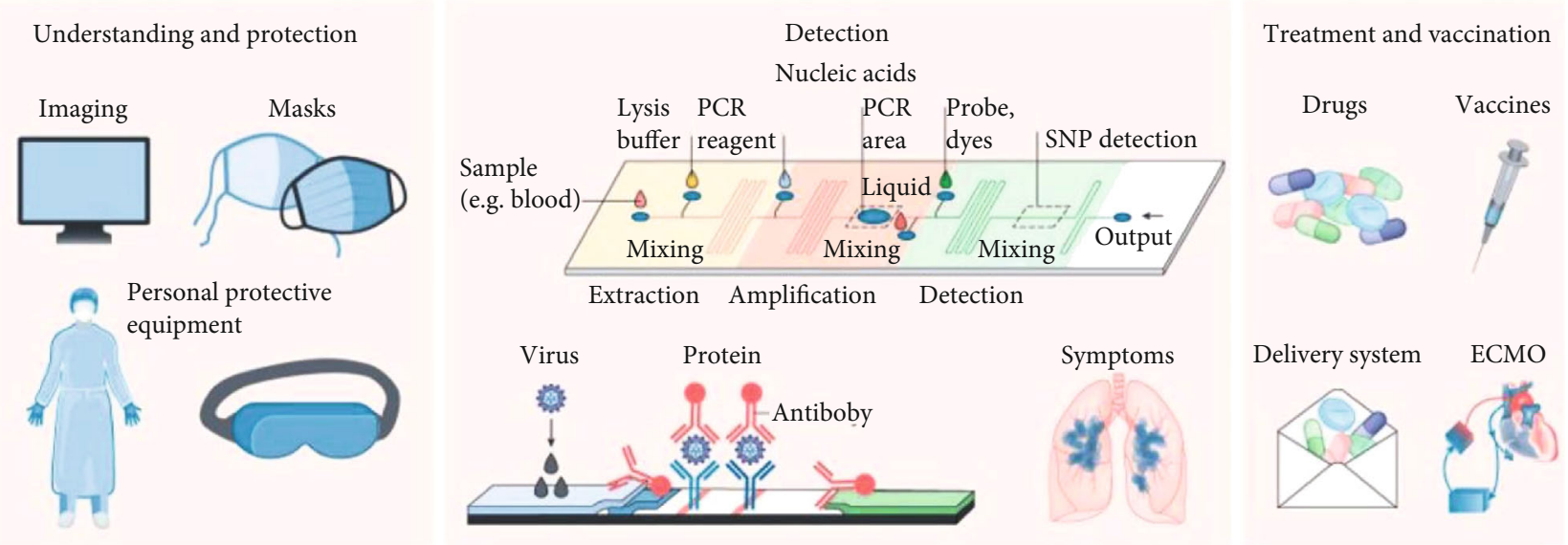

(b)

FIGURE 9: An illustration of the various roles of modern materials science employed during COVID-19 [65].

\section{BioSS/NanoBioSS for the Detention and Treatment of Diseases}

Even with the advancements in scientific knowledge, humanity is still fronted with some challenges ensuing from both communicable and noncommunicable diseases. As stated in Introduction, the prevention and early-phase detention as well as the effectiveness of the diagnosis and treatment processes are the most appropriate means for the survival and spread of such diseases. Hence, several innovative approaches such as the use of BioSS/NanoBioSS for the detention and treatment of diseases have continued to assist in this regard $[8,9,51,66-68]$.

According to several reports, presently, NanoTech innovations are felt in almost every scientific domain (such as biology, chemistry, computer science, environmental science, materials science, mathematics, physics, and engineering) and all the ensuing benefits (BioSS/NanoBioSS) are making life easier [47, 69-73]. Remarkably, in the last few years, NanoTech has been utilized in the monitoring and management of human health with auspicious results, specifically in the aspect of the treatment of cancerous complications [47, 74].
Table 1 and Table 2 encompass a summary of some studies involving the applications of BioSS/NanoBioSS for the detection of some of the most incapacitating diseases (Table 1 encompasses noncommunicable diseases, while Table 2 encompasses communicable diseases) drawn from some recent publications as adopted and modified from the broad and recent review publication work of [8].

However, the limit of detection (LoD) on this reported NanoBioSS varies and depends on some factors such as the utilized BioMK, the nature of the disease, the procedure employed in the BioSS mechanism, and the used BMs or NPs. Consequently, BioSS/NanoBioSS are predominantly characterized based on the nature of the NMs employed in the sensing mechanisms $[19,23,26]$. At the moment, there are, however, few reported commercialized BioSS for biomedical/clinical/healthcare applications; some of these are contained in Table 3 as adopted and modified from the broad review work of [8].

It was observed from Tables 1, 2, and 3 that the development of BioSS/NanoBioSS for medical purposes vis-à-vis disease detention is a contemporary dynamic aspect of modern material science (NanoTech). According to a 
TABLE 1: Summary of some reported studies on BioSS/NanoBSS for the detection of some noncommunicable diseases.

\begin{tabular}{|c|c|c|c|c|c|}
\hline BioMK & Diseases & Procedure & NPs used & LoD & Reference \\
\hline \multicolumn{6}{|c|}{ Cancerous complications } \\
\hline miRNA-182 & Cancer of the lung & ETC & $\begin{array}{l}\text { Molybdenum disulfide }\left(\mathrm{MoS}_{2}\right) / \mathrm{Ti}_{3} \mathrm{C}_{2} \\
\text { nanohybrids and modified GCE }\end{array}$ & $0.43 \mathrm{fM}$ & {$[75]$} \\
\hline miR-106a and let-7a & Gastric cancer & ETC & $\begin{array}{l}\text { AuNP and cadmium selenide (CdSe) } \\
\text { @ cadmium sulphide (CdS) QTD- } \\
\text { contained magnetic NCs (NCs) } \\
\text { polythiophene/reduced graphene (GP) } \\
\text { oxide-modified GCE }\end{array}$ & $\begin{array}{l}0.02 \mathrm{fM} \text { for let- } 7 \mathrm{a} \\
\text { and } 0.06 \mathrm{fM} \text { for } \\
\text { miR-106a }\end{array}$ & [76] \\
\hline CXCL5 & $\begin{array}{l}\text { Colorectal cancerous } \\
\text { cells CXCL5 }\end{array}$ & $\begin{array}{l}\text { ETC impedance } \\
\text { spectroscopy } \\
\text { (EIS) and } \\
\text { voltammetry } \\
\quad(\mathrm{VTM})\end{array}$ & $\begin{array}{c}\text { Chemokine receptor } 2 \text { (CXCR2) } \\
\text { attached to conducting } \\
\text { polymer-AuNP film }\end{array}$ & $0.078 \pm 0.004 \mathrm{ng} / \mathrm{mL}$ & {$[77]$} \\
\hline miR-199a-5p & $\begin{array}{l}\text { Triple-negative } \\
\text { breast cancer } \\
\quad(\mathrm{TNBC})\end{array}$ & ETC & $\begin{array}{c}\text { GCE with GP oxide (GPO) and Au } \\
\text { nanorod }\end{array}$ & $4.50 \mathrm{fM}$ & {$[78]$} \\
\hline HER-2 & Breast cancer & ETC & $\begin{array}{l}\text { AuNP grafted functionalized GP and } \\
\text { NS polyaniline (PANI) }\end{array}$ & 2 cells $\mathrm{mL}^{-1}$ & {$[79]$} \\
\hline miR-155 & Breast cancer & ETC & GPO and Au nanorod & $0.60 \mathrm{fM}$ & {$[80]$} \\
\hline BRCA1 & Breast cancer & Cyclic VTM & $\begin{array}{c}\text { ssDNA probe (BRCA1)/PANHS } \\
\text { (polycyclic aromatic nitrogen } \\
\text { heterocycles)/multiwalled } \\
\mathrm{CN} / \mathrm{GCE}\end{array}$ & $3.00 \times 10^{-18} \mathrm{~mol} \mathrm{~L}^{-1}$ & [81] \\
\hline MUC1 & $\begin{array}{l}\text { Human non-small- } \\
\text { cell lung cancerous } \\
\text { cells }\end{array}$ & $\begin{array}{l}\text { Amperometric } \\
\quad(\mathrm{APM})\end{array}$ & $\begin{array}{l}\text { MUC1 aptamer probe and benzoic } \\
\text { acid (TTBA) on AuNPs }\end{array}$ & 8 cells $/ \mathrm{mL}$ & {$[82]$} \\
\hline MAGE A2 & Lung cancer & ETC & Graphite/CN-chitosan/Ag (silver)/AB & $5.00 \mathrm{fg} \mathrm{mL}^{-1}$ & [83] \\
\hline $\begin{array}{l}\text { CpG islands of } \\
\text { adenomatous } \\
\text { polyposis coli (APC) }\end{array}$ & Colorectal cancer & FRS & $\begin{array}{l}\text { Ferrosoferric oxide }\left(\mathrm{Fe}_{3} \mathrm{O}_{4}\right) / \mathrm{Au} \text { core/ } \\
\text { shell NPs }\end{array}$ & $3.10 \times 10^{-16} \mathrm{M}$ & {$[84]$} \\
\hline \multicolumn{6}{|l|}{ Metabolic diseases } \\
\hline Uric acid (UA) & $\begin{array}{l}\text { Neuropapillitis, } \\
\text { neurodegenerative } \\
\text { diseases, sclerosis, } \\
\text { and aplastic anaemia }\end{array}$ & ETC & $\begin{array}{l}\text { Au/cobalt }(\mathrm{Co}) \text { bimetallic NPs } \\
\text { decorated hollow nanoporous carbon } \\
\text { framework (Au/Co@HNCF) }\end{array}$ & $0.023 \mu \mathrm{M}$ & {$[85]$} \\
\hline Glucose & Diabetes (DBT) & ETC & $\begin{array}{c}\text { Copper }(\mathrm{Cu}) \text {-nanoflower decorated } \\
\text { AuNPs-GO nanofiber (NF) }\end{array}$ & $0.018 \mu \mathrm{M}$ & {$[86]$} \\
\hline Vaspin & Type-2 DBT & FRS & Upconverting NPs (UC NPs) & $39.00 \mathrm{pg} \mathrm{mL}^{-1}$ & [87] \\
\hline $\begin{array}{l}\text { Ascorbic acid (AA), } \\
\text { dopamine (DA), uric } \\
\text { acid (UA), and } \\
\text { acetaminophen (AC) }\end{array}$ & $\begin{array}{l}\text { Scurvy, } \\
\text { neurodisorders }\end{array}$ & ETC & $\begin{array}{c}\text { Cerium oxide }\left(\mathrm{CeO}_{2}\right) \text { NPs-decorated } \\
\text { CN }\end{array}$ & $\begin{array}{l}3.10 \mathrm{nM} \text { for } \mathrm{AA}, \\
2.60 \mathrm{nM} \text { for } \mathrm{DA}, \\
2.40 \mathrm{nM} \text { for } \mathrm{UA}, \\
\text { and } 4.40 \mathrm{nM} \text { for } \mathrm{AC}\end{array}$ & [88] \\
\hline Vitamin D3 & $\begin{array}{l}\text { Rickets and } \\
\text { cardiovascular } \\
\text { diseases }(\mathrm{CD})\end{array}$ & ETC & $\begin{array}{l}\text { Cu NPs-nickel NPs at reduced } \\
\text { fullerene-C60 on GCE }\end{array}$ & $0.0025 \mu \mathrm{M}$ & [89] \\
\hline Leptin & $\begin{array}{l}\text { Nonalcoholic fatty } \\
\text { liver (NAFLD) }\end{array}$ & ETC & $\begin{array}{l}\text { Bovine serum albumin (BSA)/anti- } \\
\text { leptin/glutaraldehyde (Glu)/ } \\
\text { cysteamine (Cys)/AuNPs/porous } \\
\text { GP (PGP)-BP (black phosphorus)/ } \\
\text { GCE immunosensor (IMSS) was } \\
\text { employed }\end{array}$ & $0.036 \mathrm{pg} / \mathrm{mL}$ & {$[90]$} \\
\hline
\end{tabular}


TABLE 1: Continued.

\begin{tabular}{|c|c|c|c|c|c|}
\hline BioMK & Diseases & Procedure & NPs used & LoD & Reference \\
\hline Glucose & DBT & ETC & $\begin{array}{l}\text { Carbon quantum dot (CQD)/Au NPs } \\
\text { and glucose oxidase (GOx) enzymes }\end{array}$ & $17.00 \mu \mathrm{M}$ & {$[91]$} \\
\hline $\begin{array}{l}\text { 3-Hydroxybutyrate } \\
(3-\mathrm{HB})\end{array}$ & $\begin{array}{l}\text { Hyperketonemia } \\
\text { and diabetic } \\
\text { ketoacidosis (DKA) }\end{array}$ & APM & $\begin{array}{l}\text { Immobilization of the enzymes 3- } \\
\text { hydroxybutyrate dehydrogenase onto a } \\
\text { screen-printed GCE modified with } \\
\text { GPO and thionine (THI) }\end{array}$ & $1.00 \mu \mathrm{M}$ & {$[92]$} \\
\hline Glucose & DBT & APM & $\begin{array}{l}\text { Glucose oxidase immobilized on } \\
\qquad \mathrm{GPO}-\mathrm{Fe}_{3} \mathrm{O}_{4}\end{array}$ & $0.10 \mu \mathrm{M}$ & [93] \\
\hline Creatinine & $\begin{array}{l}\text { Protracted kidney } \\
\text { infection, } \mathrm{CD} \text {, and } \\
\text { type } 2 \mathrm{DBT}\end{array}$ & APM & $\begin{array}{l}\text { Immobilization of NPs of creatininase, } \\
\text { creatinase, and sarcosine oxidase onto } \\
\text { GCE }\end{array}$ & $0.01 \mu \mathrm{M}$ & [94] \\
\hline \multicolumn{6}{|l|}{ Neurological diseases } \\
\hline $\begin{array}{l}\text { Survival motor } \\
\text { neuron }(\mathrm{SMN}) \\
\text { protein }\end{array}$ & $\begin{array}{l}\text { Spinal muscular } \\
\text { atrophy }\end{array}$ & VTM & $\begin{array}{c}\text { Carbon NF-modified screen-printed } \\
\text { electrodes }\end{array}$ & $0.75 \mathrm{pg} / \mathrm{mL}$ & {$[95]$} \\
\hline miR-195 & Parkinson's disease & ETC & $\begin{array}{l}\text { Exfoliated GPO and AuNWs were } \\
\text { employed to amend the surface of } \\
\text { screen-printed GCE }\end{array}$ & $2.90 \mathrm{fM}$ & [96] \\
\hline $\mathrm{APOe}_{4}$ & $\begin{array}{l}\text { Alzheimer disease } \\
\qquad(\mathrm{AD})\end{array}$ & FRS and ETC & $\begin{array}{c}\text { Curcumin-GP QD platform coated on } \\
\text { the transparent indium-tin-oxide } \\
\text { electrode }\end{array}$ & $0.48 \mathrm{pg} \mathrm{mL}^{-1}$ & [97] \\
\hline Amyloid- $\beta$ & $\mathrm{AD}$ & FRS & Sheet-like structures of GP QD & $\begin{array}{l}\text { Dependent on the } \\
\text { FRS intensity }\end{array}$ & [98] \\
\hline $\operatorname{miR}-145$ & Multiple sclerosis & FRS & $\begin{array}{l}\text { Ag nanoclusters and hairpin } \\
\text { oligonucleotide probes, MB1 } \\
\text { and MB2 }\end{array}$ & $0.10 \mathrm{nM}$ & [99] \\
\hline$\alpha-1$ Antitrypsin & $\mathrm{AD}$ & VTM & $\begin{array}{l}\mathrm{CN} \text { and Ag NPs functionalized with } \\
\text { alkaline phosphatase-labeled } \mathrm{AB}\end{array}$ & $0.01 \mathrm{pmol} \mathrm{L}^{-1}$ & {$[100]$} \\
\hline Acetylcholine & $\mathrm{AD}$ & VTM & $\begin{array}{l}\text { Extremely permeable Au electrode } \\
\text { functionalized with } \\
\text { acetylcholinesterase (AChE) }\end{array}$ & $10.00 \mu \mathrm{mol} \mathrm{L}^{-1}$ & {$[101]$} \\
\hline Amyloid- $\beta$ & $\mathrm{AD}$ & ETC & Screen-printed GCE & $0.10 \mathrm{ng} / \mathrm{mL}$ & {$[102]$} \\
\hline \multicolumn{6}{|l|}{ Neonatal diseases } \\
\hline $\begin{array}{l}\text { C-reactive protein } \\
(\mathrm{CRP})\end{array}$ & Sepsis & ETC & $\begin{array}{l}\text { Magnetic reduced GPO/Ni (nickel)/ } \\
\text { platinum }(\mathrm{Pt}) \mathrm{NP} \text { micromotor } \\
\text { biofunctionalization on the outer layer } \\
\text { (using carbon black }(\mathrm{CB}) \text {, reduced } \\
\text { GPO, multiwalled } \mathrm{CN} \text {, and anti-CRP) }\end{array}$ & $0.80 \mu \mathrm{g} / \mathrm{mL}$ & {$[103]$} \\
\hline $\begin{array}{l}\text { Thyroid-stimulating } \\
\text { hormone (TSH) }\end{array}$ & $\begin{array}{l}\text { Thyroid } \\
\text { dysfunctioning }\end{array}$ & ETC & $\begin{array}{l}\text { Screen-printed GCE, anti-TSH AB, } \\
\text { and amino-coated Ag NPs }\end{array}$ & $0.001 \mu \mathrm{IU} / \mathrm{mL}$ & [104] \\
\hline Bilirubin (BR) & Jaundice & VTM & $\begin{array}{l}\text { Reduced GPO oxide-poly styrene } \\
\text { sulfonate (PSS) coated upon GCE }\end{array}$ & $2.00 \mu \mathrm{M}$ & {$[105]$} \\
\hline
\end{tabular}

recent review study by [26], the advancements of BioSS/ NanoBioSS are fast attaining remarkable attention in the biomedical/clinical/healthcare fields due to their wideranging applications. BioSS/NanoBioSS are presently been efficaciously employed for detecting and diagnosing, treatment of diseases, as well as in the monitoring and management of human health [26, 95, 154-158]. Hence, there should be incessant advances in the development of materials (NMs to be specific) for the fabrication of BioSS/NanoBioSS.

\section{Conclusion and Prospects of BioSS/ NanoBioSS for the Detention of Diseases}

In the recent past, the evolution of BioSS/NanoBioSS has remained as one of the dynamic areas of modern material science research (NanoTech) as attested by the large numbers of research publications. In the meantime, BioSS/NanoBioSS for detecting of diseases has stimulated a great deal of attention. The recent biomedical/clinical/healthcare applications (such as diagnostic, therapeutics, and immunization) 
TABLE 2: Summary of some reported studies on BioSS/NanoBioSS for the detection of some communicable diseases.

\begin{tabular}{|c|c|c|c|c|c|}
\hline BioMK & Diseases & Procedure & NPs used & LoD & Reference \\
\hline \multicolumn{6}{|l|}{ Viral diseases } \\
\hline $\begin{array}{l}\text { Antibodies against } \\
\text { COVID-19 }\end{array}$ & COVID-19 & $\begin{array}{l}\text { Multiplexed grating- } \\
\text { coupled FRS plasmonics }\end{array}$ & $\begin{array}{l}\text { Au-coated } \\
\text { nanoscale }\end{array}$ & $1: 1600$ dilution & [106] \\
\hline Dengue viral RNA & Dengue virus & ETC monitoring & $\begin{array}{l}\text { Methylene blue } \\
\text { conjugated } \\
\text { AuNPs }\end{array}$ & $100.00 \mathrm{fM}$ & {$[107]$} \\
\hline $\begin{array}{l}\text { S spike } \\
\text { glycoproteins }\end{array}$ & SARS-CoV-2 & ETC monitoring & $\begin{array}{l}\text { GPO and } \mathrm{Au} \\
\text { nanostars }\end{array}$ & $1.68 \times 10^{-22} \mu \mathrm{g} \mathrm{mL}^{-1}$ & {$[108]$} \\
\hline Peptide DNA/RNA & $\begin{array}{l}\text { Influenza A viruses (H1 } \\
\text { to } \mathrm{H} 16 \text { subtypes) }\end{array}$ & $\begin{array}{l}\text { Visual colorimetric assay } \\
\text { (CMA) }\end{array}$ & $\mathrm{Au}$ NPs & $2.30 \mathrm{ng}$ & [109] \\
\hline DENV proteins & Dengue viral disease & $\begin{array}{c}\text { ELISA-plate } \\
\text { spectrophotometers }\end{array}$ & Au nanorods & $1.00 \mathrm{pg}$ & [110] \\
\hline $\begin{array}{l}\text { COVID-19 spike } \\
\text { protein }\end{array}$ & COVID-19 & FET-based BioSS & GP sheets & $2.42 \times 10^{2}$ copies $/ \mathrm{mL}$ & [111] \\
\hline $\begin{array}{l}\text { Complementary } \\
\text { sequences of RdRp- } \\
\text { COVID-19, } \\
\text { ORF1ab-COVID- } \\
\text { 19, and E genes of } \\
\text { COVID-19 }\end{array}$ & COVID-19 & $\begin{array}{l}\text { PPT effect and LSPR } \\
\text { sensing transduction }\end{array}$ & $\begin{array}{c}\text { Dual- } \\
\text { dimensional } \\
\text { Au nanoislands } \\
\text { (AuNIs) }\end{array}$ & $0.22 \mathrm{pM}$ & {$[112]$} \\
\hline HBV DNA & Hepatitis B & $\begin{array}{l}\text { ETC impedance spectra } \\
\text { (EIS) }\end{array}$ & $\begin{array}{l}\text { Tin-doped } \\
\text { WO3/In2O3 } \\
\text { nanowires }\end{array}$ & $0.10 \mathrm{pM}$ to $10.00 \mu \mathrm{M}$ & [113] \\
\hline Virus DNA/RNA & $\begin{array}{l}\text { Narrowly related Zika } \\
\text { and dengue viruses }\end{array}$ & Fluorometric detection & GPO & $2.10 \times 10^{1}-5.1 \times 10^{2} \mathrm{FFU} / \mathrm{mL}$ & {$[114]$} \\
\hline Dengue viral DNA & Dengue viral disease & $\begin{array}{l}\text { Sandwich hybridization } \\
\text { strategy of DNAs }\end{array}$ & AuNPs & $1.00 \times 10^{-29} \mathrm{M}$ & [111] \\
\hline $\begin{array}{l}\text { Sialyl } \\
\text { oligosaccharide } \\
\text { receptor-mimic } \\
\text { peptide }\end{array}$ & Influenza $\mathrm{A}$ virus & $\begin{array}{l}\text { Optimized peptide } \\
\text { termination }\end{array}$ & $\begin{array}{l}\text { Boron-doped } \\
\text { diamond } \\
\text { electrode }\end{array}$ & $5.00-10.00 \mathrm{pfu} / \mathrm{sample}$ & [115] \\
\hline HCVcoreAg & Hepatitis C & $\begin{array}{l}\text { Modification of buffer } \mathrm{pH} \\
\text { from acidic to neutral }\end{array}$ & $\begin{array}{l}\text { Silicon-on- } \\
\text { insulator (SOI) } \\
\text { nanowire }\end{array}$ & $0.30 \mathrm{pg} / \mathrm{mL}$ & [116] \\
\hline $\begin{array}{l}\text { Concanavalin A } \\
\text { lectin }\end{array}$ & $\begin{array}{c}\text { Dengue type } 2, \text { Zika, } \\
\text { chikungunya, and yellow } \\
\text { fever }\end{array}$ & $\begin{array}{c}\text { Cyclic VTM and } \\
\text { impedance spectroscopy }\end{array}$ & Zinc oxide NPs & $\begin{array}{c}0.0421 \mathrm{pfu} / \mathrm{mL} \text { for } \mathrm{ZIKV} \text {, } \\
0.0437 \mathrm{pfu} / \mathrm{mL} \text { for YFV, } \\
0.062 \mathrm{pfu} / \mathrm{mL} \text { for CHIKV, and } \\
0.0382 \mathrm{pfu} / \mathrm{mL} \text { for } \mathrm{DENV}\end{array}$ & [117] \\
\hline L-lysine levels & HIV & APM BioSS & $\begin{array}{l}\text { L-lysine oxidase } \\
\text { (LOx NPs) and } \\
\text { GPO NPs }\end{array}$ & $0.01 \mu \mathrm{M}$ & [113] \\
\hline $\begin{array}{l}\text { Nonspecific } \\
\text { proteins }\end{array}$ & MERS-CoV and $\mathrm{HCoV}$ & Electrochemiluminescence & $\mathrm{Au} \mathrm{NPs}$ & $\begin{array}{c}0.40 \text { and } 1.00 \mathrm{pg} \mathrm{mL}^{-1} \text { for } \\
\mathrm{HCoV} \text { and MERS-CoV, } \\
\text { respectively }\end{array}$ & [118] \\
\hline $\begin{array}{l}\text { Hepatitis B virus } \\
\text { gene }\end{array}$ & Hepatitis B & ETC monitoring & $\begin{array}{l}\text { AMT-Au NPs- } \\
\text { PGEs }\end{array}$ & $0.86 \mu \mathrm{g} / \mathrm{mL}$ & [119] \\
\hline Viral DNA & HPV-18 & FRS assay & $\begin{array}{c}\mathrm{Ti}_{3} \mathrm{C}_{2} \\
\text { nanosheets }\end{array}$ & $100.00 \mathrm{pM}$ & {$[120]$} \\
\hline HIV-1 gene & AIDS & $\begin{array}{c}\text { Electrochemiluminescence } \\
\text { NanoBioSS }\end{array}$ & $\begin{array}{l}\text { Europium } \\
\text { sulfide } \\
\text { nanocrystals } \\
\text { (EsNCs) }\end{array}$ & $3.00 \mathrm{fM}$ to $0.30 \mathrm{nM}$ & {$[121]$} \\
\hline
\end{tabular}


TABLE 2: Continued.

\begin{tabular}{|c|c|c|c|c|c|}
\hline BioMK & Diseases & Procedure & NPs used & LoD & Reference \\
\hline $\begin{array}{l}\text { Envelop protein } \mathrm{AB} \\
\text { (Zev-Abs) }\end{array}$ & Zika virus & ETC IMSS & $\begin{array}{l}\text { Interdigitated } \\
\text { microelectrode } \\
\text { of } \mathrm{Au} \\
(\mathrm{IDE}-\mathrm{Au})\end{array}$ & $10.00 \mathrm{pM}$ & {$[122]$} \\
\hline $\begin{array}{l}\text { Virus } \\
\text { oligonucleotide }\end{array}$ & MERS-CoV & CMA & $\begin{array}{l}\text { Citrate anion- } \\
\text { stabilized } \\
\text { AgNPs }\end{array}$ & $1.53 \mathrm{nM}$ & \multirow{2}{*}[123]{} \\
\hline $\begin{array}{l}\text { Virus } \\
\text { oligonucleotide }\end{array}$ & Human papillomavirus & CMA & $\begin{array}{l}\text { Citrate anion- } \\
\text { stabilized Ag } \\
\text { NPs }\end{array}$ & $1.03 \mathrm{nM}$ & \\
\hline Surface receptor & Influenza A & Chromatographic assay & Carbon NPs & $\begin{array}{l}350 \text { TCID } 50 / \mathrm{mL} \text { (i.e., the } 50 \% \\
\text { tissue culture infectious dose) }\end{array}$ & {$[124]$} \\
\hline \multirow[t]{2}{*}{$\begin{array}{l}\text { JEV via recognition } \\
\text { cavities }\end{array}$} & $\begin{array}{l}\text { Japanese encephalitis } \\
\text { virus }\end{array}$ & FRS detection & $\begin{array}{l}\text { Magnetic } \\
\text { silicon } \\
\text { microspheres }\end{array}$ & $2.50-45.00 \mathrm{nM}$ & {$[125]$} \\
\hline & $\begin{array}{c}\text { Influenza } \mathrm{A}\left(\mathrm{H}_{1} \mathrm{~N}_{1}\right) \text { and } \\
\qquad \mathrm{A}\left(\mathrm{H}_{3} \mathrm{~N}_{2}\right)\end{array}$ & $\begin{array}{l}\text { Paper-based immunoassay } \\
\text { (IMA) }\end{array}$ & Au NPs & $\begin{array}{l}2.70 \times 10^{3}-2.70 \times 10^{4} \\
\text { plaque-forming unit per assay }\end{array}$ & {$[126]$} \\
\hline $\begin{array}{l}\text { AB specific to } \\
\text { influenza virus }\end{array}$ & Influenza $\mathrm{A}\left(\mathrm{H}_{7} \mathrm{~N}_{9}\right)$ & ETC sensor & $\begin{array}{l}\text { GPO, } \\
\text { multiwalled } \\
\mathrm{CN}\end{array}$ & $0.81 \mathrm{pg} / \mathrm{mL}$ & {$[127]$} \\
\hline $\begin{array}{l}\text { AB specific to viral } \\
\text { infection }\end{array}$ & Influenza $A$ and $B$ & IMA & Europium NPs & $\begin{array}{c}1.00 \times 10^{1} \text { to } 1.00 \times 10^{3} \text { EID } 50 / \\
\mathrm{mL}\end{array}$ & {$[128]$} \\
\hline $\begin{array}{l}\text { Specific mouse } \alpha \text {-A } \\
\text { NP mAbs }\end{array}$ & Influenza $\mathrm{A}\left(\mathrm{H}_{1} \mathrm{~N}_{1}\right)$ & FRS IMA & $\begin{array}{l}\text { Magnetic NPs } \\
\left(\mathrm{MnFe}_{2} \mathrm{O}_{4}\right)\end{array}$ & $0.007 \mathrm{HAU}$ & [129] \\
\hline & Influenza $\mathrm{A}\left(\mathrm{H}_{3} \mathrm{~N}_{2}\right)$ & FET BioSS & $\begin{array}{l}\text { Silicon } \\
\text { nanowire, } \\
\text { magnetic NPs }\end{array}$ & 29 viruses $/ \mu \mathrm{L}$ & {$[130]$} \\
\hline $\begin{array}{l}\text { DNA-based } \\
\text { detection }\end{array}$ & Influenza $\mathrm{A}\left(\mathrm{H}_{5} \mathrm{~N}_{1}\right)$ & $\begin{array}{l}\text { DNA-based microarray } \\
\text { assay (scanometric } \\
\text { detection) }\end{array}$ & $\begin{array}{l}\text { AuNPs with Ag } \\
\text { staining } \\
\text { technique }\end{array}$ & $\begin{array}{c}1.00 \times 10^{2} \mathrm{fM} \text { per assay }(\mathrm{PCR} \\
\text { fragments) } \\
1.00 \times 10^{3} \text { TCID50 per assay } \\
(\text { viral RNA) }\end{array}$ & {$[131]$} \\
\hline \multicolumn{6}{|l|}{ Bacterial diseases } \\
\hline $\begin{array}{l}\text { Bacterial target } \\
\text { DNA }\end{array}$ & S. aureus & $\begin{array}{c}\text { Targeted DNA was } \\
\text { quantified in } \\
\text { spectrophotometry at } \\
260 \mathrm{~nm} \text {; the sensitivity of } \\
\text { this method was studied } \\
\text { with PCR and gel agarose } \\
\text { electrophoresis }\end{array}$ & $\begin{array}{l}\mathrm{MNP}^{-\mathrm{TiO}_{2}-} \\
\mathrm{AP}-\mathrm{SMCC}\end{array}$ & $230.00 \mathrm{CFU} / \mathrm{mL}$ & {$[132]$} \\
\hline $\begin{array}{l}\text { Electrostatic } \\
\text { interaction of cell } \\
\text { wall and } \\
\text { concomitant } \\
\text { inhibition of } \\
\text { peroxidase activity } \\
\text { of CS-MNPs }\end{array}$ & $\begin{array}{l}\text { Gram-negative } \\
\text { Escherichia coli or the } \\
\text { Gram-positive } \\
\text { Staphylococcus aureus }\end{array}$ & CMA & $\begin{array}{l}\text { Chitosan- } \\
\text { coated iron } \\
\text { oxide magnetic } \\
\text { NPs (CS-M } \\
\text { NPs) }\end{array}$ & $\begin{array}{l}1.00 \times 10^{4} \mathrm{CFU} / \mathrm{mL} \text { by the } \\
\text { naked eye and } 1.00 \times 10^{2} \mathrm{CFU} / \\
\text { mL by spectrophotometry } \\
\text { within } 10 \mathrm{~min}\end{array}$ & [133] \\
\hline $\begin{array}{l}\text { Anti-E. coli } \mathrm{O} 157 \\
\mathrm{AB}\end{array}$ & E. coli $\mathrm{O} 157$ & $\begin{array}{l}\text { Cyclic VTM and ETC } \\
\text { impedance spectroscopy }\end{array}$ & $\mathrm{Au}$ NPs & $15.00 \mathrm{CFU} / \mathrm{mL}$ & {$[134]$} \\
\hline Anti-E. coli $\mathrm{AB}$ & E. coli & Chemiresistive BioSS & $\mathrm{Au}$ NPs & $12.00 \mathrm{CFU} / \mathrm{mL}$ & {$[135]$} \\
\hline Biofilm & $\begin{array}{l}\text { Staphylococcus } \\
\text { epidermidis }\end{array}$ & ETC sensing & $\begin{array}{l}\text { Magnesium } \\
\text { zinc oxide } \\
(\mathrm{MZO}) \mathrm{NS}\end{array}$ & $\begin{array}{l}\text { A drain current change of } \sim 80 \% \\
\text { after } \sim 200 \text { min of } S \text {. epidermidis } \\
\text { bacteria culturing }\end{array}$ & [136] \\
\hline
\end{tabular}


TABle 2: Continued.

\begin{tabular}{|c|c|c|c|c|c|}
\hline BioMK & Diseases & Procedure & NPs used & LoD & Reference \\
\hline Bacterial peptides & $\begin{array}{c}\text { Listeria monocytogenes } \\
\text { and Staphylococcus } \\
\text { aureus }\end{array}$ & ETC BioSS & $\mathrm{Au}$ NPs & $\begin{array}{c}3.00 \mathrm{CFU} / \mathrm{mL} \text { for } \\
\text { Staphylococcus aureus and } \\
9.00 \mathrm{CFU} / \mathrm{mL} \text { for Listeria } \\
\text { monocytogenes }\end{array}$ & {$[137]$} \\
\hline $\begin{array}{l}\text { Bacteria's target } \\
\text { DNA }\end{array}$ & $\begin{array}{c}\text { Foodborne bacteria } \\
\text { including Escherichia coli } \\
\mathrm{O}_{157}: \mathrm{H}_{7} \text {, Vibrio } \\
\text { parahaemolyticus, } \\
\text { Salmonella, } \\
\text { Staphylococcus aureus, } \\
\text { Listeria monocytogenes, } \\
\text { Shigella, etc. }\end{array}$ & $\begin{array}{c}\text { Amplified microcantilever } \\
\text { array BioSS }\end{array}$ & $\mathrm{Au}$ NPs & $0.005-0.040 \mathrm{fM}$ or $1-9$ cells $/ \mathrm{mL}$ & {$[138]$} \\
\hline $\begin{array}{l}\text { Receptor-binding } \\
\text { protein of bacteria }\end{array}$ & $\begin{array}{c}\text { Escherichia coli, } \\
\text { Pseudomonas } \\
\text { aeruginosa, and Vibrio } \\
\text { cholerae }\end{array}$ & CMA & $\mathrm{Au} \mathrm{NPs}$ & $\sim 100$ cells & [139] \\
\hline $\begin{array}{l}\text { Mycobacterium } \\
\text { tuberculosis } \\
\text { oligonucleotide }\end{array}$ & $\begin{array}{c}\text { Mycobacterium } \\
\text { tuberculosis (MTB) }\end{array}$ & CMA & $\begin{array}{l}\text { Citrate anion- } \\
\text { stabilized (Ag } \\
\text { NPs) }\end{array}$ & $1.27 \mathrm{nM}$ & [123] \\
\hline \multicolumn{6}{|l|}{ Fungal diseases } \\
\hline Fungal spores & Aspergillus niger & CMA & $\begin{array}{l}\text { Peptide- } \\
\text { modified Au } \\
\text { NPs }\end{array}$ & 50 spores & {$[140]$} \\
\hline $\begin{array}{l}\text { Concanavalin A } \\
\text { (ConA) and wheat } \\
\text { germ agglutinin } \\
\text { (WGA) lectins }\end{array}$ & Candida spp. & Impedimetric BioSS & $\begin{array}{l}\text { Lectin- } \\
\text { modified Au } \\
\text { NPs }\end{array}$ & $1.00 \times 10^{2}-1.00 \times 10^{6} \mathrm{CFU} / \mathrm{mL}$ & [141] \\
\hline Protein BioMK & $\begin{array}{l}\text { Aspergillus fumigatus } \\
\text { allergen Asp f } 1\end{array}$ & CMA & $\begin{array}{l}\text { Magneto-BioSS } \\
\text { biochip }\end{array}$ & $\sim 100.00 \mathrm{pg} / \mathrm{mL}$ & {$[142]$} \\
\hline \multicolumn{6}{|l|}{ Parasitic diseases } \\
\hline $\mathrm{AB}$ as receptor & Malaria & ETC BioSS & $\begin{array}{l}\text { Platinum NPs } \\
\quad(\text { Pt NPs) }\end{array}$ & $8.00 \mathrm{ng} / \mathrm{mL}$ & {$[143]$} \\
\hline $\mathrm{pLDH}$ & Malaria & $\begin{array}{l}\text { EIS: ETC impedance } \\
\text { spectroscopy }\end{array}$ & GCE & $0.50 \mathrm{fM}$ & {$[144]$} \\
\hline$\beta$-Hematin & P. berghei, $P$. falciparum & ETC NS & $\mathrm{Au}-\mathrm{CuO}$ & $\begin{array}{l}3.60-4.80 \mathrm{mM} \\
0.65-1.35 \mathrm{mM}\end{array}$ & [145] \\
\hline Bilharzia AB & Bilharzia disease & ETC NanoBioSS & $\begin{array}{l}\text { Nanostrip with } \\
\text { immobilized } \\
\text { Au NPs }\end{array}$ & $8.39 \times 10^{-2} \mathrm{ng} / \mathrm{mL}$ & {$[146]$} \\
\hline
\end{tabular}

TABLE 3: Some reported commercialized BioSS/NanoBioSS for biomedical/clinical/healthcare applications.

\begin{tabular}{|c|c|c|c|}
\hline Target analyte & Linked disorder & Type of BioSS/NanoBioSS & Reference \\
\hline Glucose & DBT & $\begin{array}{c}\text { Enzymatic-ETC NanoBioSS, lateral flow (LF) immunochromatographic } \\
\text { (ICM) assays reverse iontophoresis }\end{array}$ & {$[147]$} \\
\hline $\begin{array}{l}\text { Human chorionic } \\
\text { gonadotropin (hCG) }\end{array}$ & $\begin{array}{l}\text { Gestation, fertility, } \\
\text { and ovulation }\end{array}$ & LF ICM assay, FRS-labeled AB assay & {$[148]$} \\
\hline Streptococci spp. & $\begin{array}{l}\text { Diseases of the throat } \\
\text { or skin }\end{array}$ & LF ICM assay, FRS-labeled AB assay & $\begin{array}{l}{[149,} \\
150]\end{array}$ \\
\hline $\begin{array}{l}\text { Mycobacterium } \\
\text { tuberculosis }\end{array}$ & Tuberculosis & LF ICM assay, FRS-labeled AB assay & {$[151]$} \\
\hline Alpha-fetoprotein (AFP) & $\begin{array}{l}\text { Cancerous } \\
\text { complications }\end{array}$ & LF ICM assay, ETC & {$[152]$} \\
\hline Bacillus anthracis & Anthrax & Standard LF assay, FRS-labeled AB assay & {$[153]$} \\
\hline
\end{tabular}


of BioSS/NanoBioSS mechanism via the development of NanoTech present an encouraging procedure for the effective and precise detection of protein BioMK allied with various diseases. Be that as it may, this recent review study presents a facile review of some of the reported biomedical/clinical/ healthcare applications and potentialities of NanoBioSS particularly for some deadly diseases, emphasizing some of the potential BioMK that could detect such diseases. As observed from most reported research publications, there are limited approaches that are concentrating in the direction for decreasing sample volumes or the duration of the analysis.

Consequently, there is still a great deal of work that needs to be carried out before NanoBioSs will be broadly employed in biomedical/clinical/healthcare laboratories as a replacement for just research laboratory purposes alone. A vibrant direction of imminent research is still in the aspect of molecular diagnostics for the accomplishment of advanced permanence and sensitivity. In the interim, diagnostic validation by processing an advanced quantity of biomedical/clinical/healthcare samples coming from persons infected with various diseases is required. Also, some components such as the nature of the protein, enzyme antigen, or/and other BMs, in addition to the concerned immobilization, should be considered. It is also suggested that the commercial approach to NanoBioSS from these useful reported researches should be one of the strategic aspects that require appropriate attention especially with funding and manpower in imminent research. Nevertheless, to exclusively achieve the biomedical/clinical/healthcare potentialities of NanoBioSS, additional and more researches should be executed and NanoBioSS could be pertinent in a complex matrix and extreme settings. Future research approaches should also hypothesize and conceptualize the implementations of innovative computational procedures such as big data analytics, Internet of Things, artificial intelligence, deep learning approachability, and microchip-built devices (all these are embedded in what is known as smart systems) interconnected with NanoBioSS for various biomedical/clinical/ healthcare applications vis-à-vis the detection of diseases. Consequently, biomedical/clinical/healthcare investigations that recognise these smart systems interconnected with NanoBioSS should be reinvigorated for the development of prominent future detection of diseases (diagnostics).

\section{Abbreviations}

$\begin{array}{ll}\text { APM: } & \text { Amperometric } \\ \text { AB: } & \text { Antibody } \\ \text { BioMK: } & \text { Biomarker } \\ \text { BMs: } & \text { Biomolecules } \\ \text { BioSS: } & \text { Biosensor } \\ \text { 3Bs: } & \text { Blood-brain barrier } \\ \text { CN: } & \text { Carbon nanotube } \\ \text { CMA: } & \text { Colorimetric assay } \\ \text { ETC: } & \text { Electrochemical } \\ \text { FET: } & \text { Field-effect transistor } \\ \text { FRS: } & \text { Fluorescence } \\ \text { GCE: } & \text { Glassy carbon electrode } \\ \text { GP: } & \text { Graphene }\end{array}$

$\begin{array}{ll}\text { ICM: } & \text { Immunochromatographic } \\ \text { IMSS: } & \text { Immunosensor } \\ \text { IMA: } & \text { Immunoassay } \\ \text { ITO-NW: } & \text { Indiumtin oxide nanowires } \\ \text { LF: } & \text { Lateral flow } \\ \text { LoD: } & \text { Limit of detention } \\ \text { NanoBioSS: } & \text { Nanobiosensor } \\ \text { NCs: } & \text { Nanocomposites } \\ \text { NF: } & \text { Nanofiber } \\ \text { NMs: } & \text { Nanomaterials } \\ \text { NPs: } & \text { Nanoparticles } \\ \text { NanoTech: } & \text { Nanotechnology } \\ \text { NS: } & \text { Nanostructure } \\ \text { PtNP: } & \text { Platinum nanoparticle } \\ \text { rGPO: } & \text { Reduced graphene oxide } \\ \text { QD: } & \text { Quantum dot } \\ \text { TdT: } & \text { Terminal deoxynucleotidyl transferase } \\ \text { VTM: } & \text { Voltammetry. }\end{array}$

\section{Data Availability}

Completely, data produced or investigated during this work were involved in this submitted article.

\section{Conflicts of Interest}

There is no conflict of interest to declare.

\section{Authors' Contributions}

All authors contributed significantly to this review study.

\section{Acknowledgments}

The authors are sincerely thankful to their respective institutions, as well as authors whose publications were used for this review study.

\section{References}

[1] Z. Khorrami, M. Rezapour, K. Etemad et al., "The patterns of non-communicable disease multimorbidity in Iran: a multilevel analysis," Scientific Reports, vol. 10, no. 1, p. 303, 2020.

[2] WHO, Non-communicable diseases progress monitor 2020, World Health Organisation (WHO), 2020.

[3] G. Pascarella, A. Strumia, C. Piliego et al., "COVID-19 diagnosis and management: a comprehensive review," Journal of Internal Medicine, vol. 288, no. 2, pp. 192-206, 2020.

[4] D. Dhawan and S. Sharma, "Abdominal obesity, adipokines and non-communicable diseases," The Journal of Steroid Biochemistry and Molecular Biology, vol. 203, p. 105737, 2020.

[5] N. Bahner, P. Reich, D. Frense, M. Menger, K. Schieke, and Beckmann, "An aptamer-based biosensor for detection of doxorubicin by electrochemical impedance spectroscopy," Analytical and Bioanalytical Chemistry, vol. 410, no. 5, pp. 1453-1462, 2018.

[6] U. Aigbe, R. Onyancha, K. Ukhurebor, and K. Obodo, "Removal of fluoride ions using a polypyrrole magnetic nanocomposite influenced by a rotating magnetic field," RSC Advances, vol. 10, no. 1, pp. 595-609, 2020. 
[7] K. Ukhurebor, H. Athar, C. Adetunji, U. Aigbe, R. Onyancha, and O. Abifarin, "Environmental implications of petroleum spillages in the Niger Delta Region of Nigeria: a review," Journal of Environmental Management, vol. 293, article 112872, 2021.

[8] R. George Kerry, K. E. Ukhurebor, S. Kumari et al., “A comprehensive review on the applications of nano-biosensorbased approaches for non-communicable and communicable disease detection," Biomaterials Science, vol. 9, no. 10, pp. 3576-3602, 2021.

[9] Y. Huang, J. Xu, J. Liu, X. Wang, and B. Chen, "Diseaserelated detection with electrochemical biosensors: a review," Sensors, vol. 17, no. 10, p. 2375, 2017.

[10] S. Singh, S. Dhanjal, Sonali et al., "An insight in bacteriophage based biosensors with focus on their detection methods and recent advancements," Environmental Technology and Innovation, vol. 20, article 101081, 2020.

[11] J. Kreuter, "Nanoparticles-a historical perspective," International Journal of Pharmaceutics, vol. 331, no. 1, pp. 1-10, 2007.

[12] A. El-Sayed and M. Kamel, "Advances in nanomedical applications: diagnostic, therapeutic, immunization, and vaccine production," Environmental Science and Pollution Research, vol. 27, no. 16, pp. 19200-19213, 2020.

[13] A. Jurj, C. Braicu, L.-A. Pop, C. Tomuleasa, C. Gherman, and I. Berindan-Neagoe, "The new era of nanotechnology, an alternative to change cancer treatment," Drug Design, Development and Therapy, vol. Volume 11, pp. 28712890, 2017.

[14] Y. Zhou, Z. Peng, E. Seven, and R. M. Leblanc, "Crossing the blood-brain barrier with nanoparticles," Journal of Controlled Release, vol. 270, pp. 290-303, 2018.

[15] D. Talukdar, R. Sharma, A. Sharma, and R. Kumar, "Drug resistance in tuberculosis: how to counter the menace?," Current Pharmaceutical Biotechnology, vol. 15, no. 12, pp. 11581165, 2014.

[16] K. Sridharan and N. Gogtay, "Therapeutic nucleic acids: current clinical status," British Journal of Clinical Pharmacology, vol. 82, no. 3, pp. 659-672, 2016.

[17] M. Riley and W. Vermerris, "Recent advances in nanomaterials for gene delivery-a review," Nanomaterials, vol. 7, no. 5, p. 94, 2017.

[18] R. Rebelo, A. Barbosa, D. Caballero et al., "3D biosensors in advanced medical diagnostics of high mortality diseases," Biosensors \& Bioelectronics, vol. 130, pp. 20-39, 2019.

[19] J. Yoon, M. Shin, T. Lee, and J.-W. Choi, "Highly sensitive biosensors based on biomolecules and functional nanomaterials depending on the types of nanomaterials: a perspective review," Materials, vol. 13, no. 2, p. 299, 2020.

[20] D. Bruen, C. Delaney, L. Florea, and D. Diamond, "Glucose sensing for diabetes monitoring: recent developments," Sensors, vol. 17, no. 8, p. 2017, 2017.

[21] A. L. Morais, P. Rijo, M. B. Batanero Hernán, and M. Nicolai, "Biomolecules and electrochemical tools in chronic noncommunicable disease surveillance: a systematic review," Biosensors, vol. 10, no. 9, p. 121, 2020.

[22] K. Ukhurebor, "The role of biosensor in climate smart organic agriculture towards agricultural and environmental sustainability," in Agrometeorology, R. Meena, Ed., IntechOpen, London, UK, 2020.
[23] A. C. Carpenter, I. T. Paulsen, and T. C. Williams, "Blueprints for biosensors: design, limitations, and applications," Genes, vol. 9, no. 8, p. 375, 2018.

[24] D. Rodrigues, A. Barbosa, R. Rebelo, I. Kwon, R. Reis, and V. Correlo, "Skin-integrated wearable systems and implantable biosensors: a comprehensive review," Biosensors, vol. 10 , no. 7, p. 79, 2020.

[25] K. E. Ukhurebor and C. O. Adetunji, "Relevance of biosensor in climate smart organic agriculture and their role in environmental sustainability: what has been done and what we need to do," in Biosensors in Agriculture: Recent Trends and Future Perspectives, R. Pudake, U. Jain, and C. Kole, Eds., pp. 115136, Springer Nature, 2021.

[26] P. Mohankumar, J. Ajayan, T. Mohanraj, and R. Yasodharan, "Recent developments in biosensors for healthcare and biomedical applications: a review," Measurement, vol. 167, article 108293, 2021.

[27] R. Onyancha, U. Aigbe, K. Ukhurebor, and P. Muchiri, “Facile synthesis and applications of carbon nanotubes in heavymetal remediation and biomedical fields: a comprehensive review," Journal of Molecular Structure, vol. 1238, article 130462, 2021.

[28] K. Ukhurebor, C. Adetunji, A. Bobadoye et al., "Bionanomaterials for biosensor technology," in Bionanomaterials: Fundamentals and Biomedical Applications, R. Singh and K. Singh, Eds., Institute of Physics Publishing, 2021.

[29] S. Kamel and T. A. Khattab, "Recent advances in cellulosebased biosensors for medical diagnosis," Biosensors, vol. 10, no. 6 , p. $67,2020$.

[30] S. Metkar and K. Girigoswami, "Diagnostic biosensors in medicine - a review," Biocatalysis and Agricultural Biotechnology, vol. 17, pp. 271-283, 2019.

[31] K. Girigoswami and N. Akhtar, "Nanobiosensors and fluorescence-based biosensors: an overview," International Journal of Nano Dimension, vol. 10, no. 1, pp. 1-17, 2019.

[32] K. Girigoswami and A. Girigoswami, "A review on the role of nanosensors in detecting cellular miRNA expression in colorectal cancer," Endocrine, Metabolic \& Immune Disorders Drug Targets, vol. 21, no. 1, pp. 12-26, 2021.

[33] V. Thendral, T. Dharshni, M. Ramalakshmi, A. Girigoswami, and K. Girigoswami, "Cerium oxide nanocluster based nanobiosensor for ROS detection," Biocatalysis and Agricultural Biotechnology, vol. 19, article 101124, 2019.

[34] T. Tan, M. Gochoo, Y. Chen et al., "Ubiquitous emergency medical service system based on wireless biosensors, traffic information, and wireless communication technologies: development and evaluation," Sensors, vol. 17, no. 12, p. 202, 2017.

[35] J. Kudr, P. Michalek, L. Ilieva, V. Adam, and O. Zitka, "COVID-19: a challenge for electrochemical biosensors," Trends in Analytical Chemistry, vol. 136, article 116192, 2021.

[36] J. Yu, A. Yang, N. Wang et al., "Highly sensitive detection of caspase- 3 activity based on peptide-modified organic electrochemical transistor biosensors," Nanoscale, vol. 13, no. 5, pp. 2868-2874, 2021.

[37] K. E. Ukhurebor, K. B. Singh, V. Nayak, and G. UkEghonghon, "Influence of the SARS-CoV-2 pandemic: a review from the climate change perspective," Environmental Science: Processes \& Impacts, vol. 23, no. 8, pp. 10601078, 2021. 
[38] S. Bahl, M. Javaid, A. Bagha et al., "Biosensors applications in fighting COVID-19 pandemic," Apollo Medicine, vol. 17, no. 3, pp. 221-223, 2020.

[39] K. Un, C. Wong, Y. Lau et al., "Observational study on wearable biosensors and machine learning-based remote monitoring of COVID-19 patients," Scientific Reports, vol. 11, no. 1, pp. 4388-4389, 2021.

[40] P. Chandra, "Miniaturized label-free smartphone assisted electrochemical sensing approach for personalized COVID19 diagnosis," Sensors International, vol. 1, article 100019, p. 100019, 2020.

[41] J. Choi, "Development of point-of-care biosensors for COVID-19," Frontiers in Chemistry, vol. 8, p. 517, 2020.

[42] A. Haleem, M. Javaid, R. Singh, R. Suman, and S. Rab, "Biosensors applications in medical field: a brief review," Sensors International, vol. 2, article 100100, 2021.

[43] H. Alhadrami, "Biosensors: classifications, medical applications, and future prospective," Biotechnology and Applied Biochemistry, vol. 65, no. 3, pp. 497-508, 2018.

[44] N. Durmuş, R. Lin, M. Kozberg, D. Dermici, A. Khademhosseini, and U. Demirci, "Encyclopedia of microfluidics and nanofluidics," Springer Science \& Business Media, 2015.

[45] W. Nwankwo and K. Ukhurebor, "Nanoinformatics: opportunities and challenges in the development and delivery of healthcare products in developing countries," IOP Conference Series: Earth and Environmental Science, vol. 655, no. 1, article 012018, 2021.

[46] W. Nwankwo, A. Olayinka, and K. Ukhurebor, "Why design of projects on nanomedicine development and clinical applications may fail?," in International Conference in Mathematics, Computer Engineering and Computer Science (ICMCECS), Lagos, Nigeria, Lagos, Nigeria, 2020.

[47] S. Bayda, M. Adeel, T. Tuccinardi, M. Cordani, and F. Rizzolio, "The history of nanoscience and nanotechnology: from chemical-physical applications to nanomedicine," Molecules, vol. 25, no. 1, p. 112, 2020.

[48] C. Adetunji, W. Nwankwo, K. Ukhurebor, A. Olayinka, and A. Makinde, "Application of biosensor for the identification of pests and diseases mitigating against increase in agricultural production: recent advances," in Biosensors in Agriculture: Recent Trends and Future Perspectives, R. Pudake, U. Jain, and C. Kole, Eds., pp. 169-189, Springer Nature, 2021.

[49] K. Ukhurebor, U. Aigbe, R. Onyancha et al., "Effect of hexavalent chromium on the environment and removal techniques: a review," Journal of Environmental Management, vol. 280, article 111809, 2021.

[50] N. Debnath and S. Das, "Nanobiosensor: current trends and applications," in NanoBioMedicine, S. Saxena and S. Khurana, Eds., pp. 389-409, Springer Nature, 2020.

[51] P. Mehrotra, "Biosensors and their applications - a review," Journal of Oral Biology and Craniofacial Research, vol. 6, no. 2, pp. 153-159, 2016.

[52] Y. Wang, R. Yuan, Y. Chaia et al., "Direct electron transfer: electrochemical glucose biosensor based on hollow Pt nanosphere functionalized multiwall carbon nanotubes," Journal of Molecular Catalysis B: Enzymatic, vol. 71, no. 3-4, pp. 146-151, 2011.

[53] S. Kim, J. Rusling, and F. Papadimitrakopoulos, "Carbon nanotubes for electronic and electrochemical detection of biomolecules," Advanced Materials, vol. 19, no. 20, pp. 3214-3228, 2007.

[54] J. Claussen, A. Franklin, A. ul Haque, D. Porterfield, and T. Fisher, "Electrochemical biosensor of nanocubeaugmented carbon nanotube networks," ACS Nano, vol. 3, no. 1, pp. 37-44, 2009.

[55] R. Rakhi, K. Sethupathi, and S. Ramaprabhu, "A glucose biosensor based on deposition of glucose oxidase onto crystalline gold nanoparticle modified carbon nanotube electrode," The Journal of Physical Chemistry. B, vol. 113, no. 10, pp. 31903194, 2009.

[56] J. Wang, "Nanomaterial-based electrochemical biosensors," Analyst, vol. 130, no. 4, pp. 421-426, 2005.

[57] J. Ryu, B. G. Park, S. Kim, and Y. J. Park, "Effects of surface area on electrochemical performance of $\mathrm{Li}\left[\mathrm{Ni}_{0.2-}\right.$ $\mathrm{Li}_{0.2} \mathrm{Mn}_{0.6} \mathrm{O}_{2}$ cathode material," Journal of Applied Electrochemistry, vol. 39, no. 7, pp. 1059-1066, 2009.

[58] H. A. Rafiee-Pour, M. Behpour, and M. Keshavarz, "A novel label-free electrochemical miRNA biosensor using methylene blue as redox indicator: application to breast cancer biomarker miRNA-21," Biosensors \& Bioelectronics, vol. 77, pp. 202-207, 2016.

[59] M. Rizwan, N. Mohd-Naim, and M. Ahmed, "Trends and advances in electrochemiluminescence nanobiosensors," Sensors, vol. 18, no. 2, p. 166, 2018.

[60] M. Pirzada and Z. Altintas, "Nanomaterials for healthcare biosensing applications," Sensors, vol. 19, no. 23, p. 5311, 2019.

[61] A. Hashem, M. Hossain, A. Marlinda, M. Mamun, K. Simarani, and M. Johan, "Nanomaterials based electrochemical nucleic acid biosensors for environmental monitoring: a review," Applied Surface Science Advances, vol. 4, article 100064, 2021.

[62] Y. Zhu, J. Wu, L. Han et al., "Nanozyme sensor arrays based on heteroatom-doped graphene for detecting pesticides," Analytical Chemistry, vol. 92, no. 11, pp. 7444-7452, 2020.

[63] X. Jiang, W. Wang, L. Lu, D. Zheng, H. Chen, and L. Xu, "Electrochemical immunosensor for rapid detection of chlorpyrifos in agricultural products," Transactions of the Chinese Society of Agricultural Engineering, vol. 30, pp. 278-283, 2014.

[64] R. Onyancha, K. Ukhurebor, U. Aigbe et al., "A systematic review on the detection and monitoring of toxic gases using carbon nanotube-based biosensors," Sensing and BioSensing Research, vol. 34, article 100463, 2021.

[65] Z. Tang, N. Kong, X. Zhang et al., "A materials-science perspective on tackling COVID-19," Nature Reviews Materials, vol. 5, no. 11, pp. 847-860, 2020.

[66] L. Reverté, B. Prieto-Simón, and M. Campàs, "New advances in electrochemical biosensors for the detection of toxins: nanomaterials, magnetic beads and microfluidics systems. A review," Analytica Chimica Acta, vol. 908, pp. 8-21, 2016.

[67] J. Ni, Q. Wang, W. Yang et al., "Immobilization free electrochemical biosensor for folate receptor in cancer cells based on terminal protection," Biosensors \& Bioelectronics, vol. 86, pp. 496-501, 2016.

[68] J. Mandli, H. Mohammadi, and A. Amine, "Electrochemical DNA sandwich biosensor based on enzyme amplified microRNA-21 detection and gold nanoparticles," Bioelectrochemistry, vol. 116, pp. 17-23, 2017. 
[69] R. Chaudhary, G. Bhusari, A. Tiple et al., "Metal/metal oxide nanoparticles: toxicity, applications, and future prospects," Current Pharmaceutical Design, vol. 25, no. 37, pp. 40134029, 2019.

[70] A. Potbhare, R. Chaudhary, P. Chouke et al., "Phytosynthesis of nearly monodisperse $\mathrm{CuO}$ nanospheres using Phyllanthus reticulatus/Conyza bonariensis and its antioxidant/antibacterial assays," Materials Science and Engineering: C, vol. 99, pp. 783-793, 2019.

[71] P. Chouke, A. Potbhare, K. Dadure et al., "An antibacterial activity of Bauhinia racemosa assisted $\mathrm{ZnO}$ nanoparticles during lunar eclipse and docking assay," Materials Today: Proceedings, vol. 29, pp. 815-821, 2020.

[72] M. Umekar, R. Chaudhary, G. Bhusari, and A. Potbhare, "Fabrication of zinc oxide-decorated phytoreduced graphene oxide nanohybrid via Clerodendrum infortunatum," Emerging Materials Research, vol. 10, no. 1, pp. 75-84, 2021.

[73] R. Mishra, P. Mishra, K. Verma et al., "Electrospinning production of nanofibrous membranes," Environmental Chemistry Letters, vol. 17, no. 2, pp. 767-800, 2019.

[74] A. Singh, M. Choudhary, S. Kaur, S. Singh, and K. Arora, "Molecular functionalization of carbon nanomaterials for immuno-diagnosis of cancer," Materials Today: Proceedings, vol. 3, no. 2, pp. 157-161, 2016.

[75] L. Liu, Y. Wei, S. Jiao, S. Zhu, and X. Liu, "A novel label-free strategy for the ultrasensitive miRNA-182 detection based on $\mathrm{MoS}_{2} / \mathrm{Ti}_{3} \mathrm{C}_{2}$ nanohybrids," Biosensors \& Bioelectronics, vol. 137, pp. 45-51, 2019.

[76] M. Daneshpour, B. Karimi, and K. Omidfar, "Simultaneous detection of gastric cancer-involved miR-106a and let-7a through a dual-signal-marked electrochemical nanobiosensor," Biosensors \& Bioelectronics, vol. 109, pp. 197-205, 2018.

[77] S. Chung, P. Chandra, J. Koo, and Y. Shim, "Development of a bifunctional nanobiosensor for screening and detection of chemokine ligand in colorectal cancer cell line," Biosensors \& Bioelectronics, vol. 100, pp. 396-403, 2018.

[78] A. Ebrahimi, I. Nikokar, M. Zokaei, and E. Bozorgzadeh, "Design, development and evaluation of microRNA-199a$5 p$ detecting electrochemical nanobiosensor with diagnostic application in triple negative breast cancer," Talanta, vol. 189, pp. 592-598, 2018.

[79] R. Salahandish, A. Ghaffarinejad, S. Naghib, A. Majidzadeh, H. Zargartalebi, and A. Sanati-Nezhad, "Nano-biosensor for highly sensitive detection of HER2 positive breast cancer," Biosensors \& Bioelectronics, vol. 117, pp. 104-111, 2018.

[80] M. Azimzadeh, M. Rahaie, N. Nasirizadeh, K. Ashtari, and H. Naderi-Manesh, "An electrochemical nanobiosensor for plasma miRNA-155, based on graphene oxide and gold nanorod, for early detection of breast cancer," Biosensors \& Bioelectronics, vol. 77, pp. 99-106, 2016.

[81] A. Benvidi, M. Tezerjani, S. Jahanbani, M. Mazloum Ardakani, and S. Moshtaghioun, "Comparison of impedimetric detection of DNA hybridization on the various biosensors based on modified glassy carbon electrodes with PANHS and nanomaterials of RGO and MWCNTs," Talanta, vol. 147, pp. 621-627, 2016.

[82] T. Mir, J. Yoon, N. Gurudatt, M. Won, and Y. Shim, "Ultrasensitive cytosensing based on an aptamer modified nanobiosensor with a bioconjugate: detection of human non-smallcell lung cancer cells," Biosensors \& Bioelectronics, vol. 74, pp. 594-600, 2015.
[83] M. Choudhary, A. Singh, S. Kaur, and K. Arora, "Enhancing lung cancer diagnosis: electrochemical simultaneous bianalyte immunosensing using carbon nanotubes-chitosan nanocomposite," Applied Biochemistry and Biotechnology, vol. 174, no. 3, pp. 1188-1200, 2014.

[84] M. Dadmehr, M. Hosseini, S. Hosseinkhani et al., "DNA methylation detection by a novel fluorimetric nanobiosensor for early cancer diagnosis," Biosensors \& Bioelectronics, vol. 60, pp. 35-44, 2014.

[85] K. Wang, C. Wu, F. Wang, M. Liao, and G. Jiang, "Bimetallic nanoparticles decorated hollow nanoporous carbon framework as nanozyme biosensor for highly sensitive electrochemical sensing of uric acid," Biosensors and Bioelectronics, vol. 150, article 111869, 2020.

[86] S. Baek, J. Roh, C. Park et al., "Cu-nanoflower decorated gold nanoparticles-graphene oxide nanofiber as electrochemical biosensor for glucose detection," Materials Science and Engineering: $C$, vol. 107, article 110273, 2020.

[87] M. Ali, M. Sajid, M. Khalid et al., "A fluorescent lateral flow biosensor for the quantitative detection of vaspin using upconverting nanoparticles," Spectrochimica Acta Part A: Molecular and Biomolecular Spectroscopy, vol. 226, article 117610, 2020.

[88] T. Iranmanesh, M. Foroughi, S. Jahani, M. Shahidi Zandi, and H. Hassani Nadiki, "Green and facile microwave solvent-free synthesis of $\mathrm{CeO}_{2}$ nanoparticle-decorated CNTs as a quadruplet electrochemical platform for ultrasensitive and simultaneous detection of ascorbic acid, dopamine, uric acid and acetaminophen," Talanta, vol. 207, article 120318, 2020.

[89] T. Anusha, K. Bhavani, J. Kumar, and P. Brahman, "Designing and fabrication of electrochemical nanosensor employing fullerene- $\mathrm{C}_{60}$ and bimetallic nanoparticles composite film for the detection of vitamin $\mathrm{D}_{3}$ in blood samples," Diamond and Related Materials, vol. 104, article 107761, 2020.

[90] J. Cai, X. Gou, B. Sun et al., "Porous graphene-black phosphorus nanocomposite modified electrode for detection of leptin," Biosensors \& Bioelectronics, vol. 137, pp. 88-95, 2019.

[91] V. Buk, M. Pemble, and K. Twomey, "Fabrication and evaluation of a carbon quantum dot/gold nanoparticle nanohybrid material integrated onto planar micro gold electrodes for potential bioelectrochemical sensing applications," Electrochimica Acta, vol. 293, pp. 307-317, 2019.

[92] G. Martínez-García, E. Pérez-Julián, L. Agüí et al., “An electrochemical enzyme biosensor for 3-hydroxybutyrate detection using screen-printed electrodes modified by reduced graphene oxide and thionine," Biosensors, vol. 7, no. 4, p. 50, 2017.

[93] S. Pakapongpan and R. Poo-arporn, "Self-assembly of glucose oxidase on reduced graphene oxide-magnetic nanoparticles nanocomposite-based direct electrochemistry for reagentless glucose biosensor," Materials Science and Engineering: C, vol. 76, pp. 398-405, 2017.

[94] P. Kumar, R. Jaiwal, and C. Pundir, "An improved amperometric creatinine biosensor based on nanoparticles of creatininase, creatinase and sarcosine oxidase," Analytical Biochemistry, vol. 537, pp. 41-49, 2017.

[95] S. Eissa, N. Alshehri, A. Rahman, M. Dasouki, K. Abu-Salah, and M. Zourob, "Electrochemical immunosensors for the detection of survival motor neuron (SMN) protein using different carbon nanomaterials-modified electrodes," Biosensors \& Bioelectronics, vol. 101, pp. 282-289, 2018. 
[96] Z. Aghili, N. Nasirizadeh, A. Divsalar, S. Shoeibi, and P. Yaghmaei, "A highly sensitive miR-195 nanobiosensor for early detection of Parkinson's disease," Artificial Cells, Nanomedicine, and Biotechnology, vol. 46, no. sup1, pp. 3240, 2018.

[97] A. Mars, M. Hamami, L. Bechnak, D. Patra, and N. Raouafi, "Curcumin-graphene quantum dots for dual mode sensing platform: Electrochemical and fluorescence detection of APOe4, responsible of Alzheimer's disease," Analytica Chimica Acta, vol. 1036, pp. 141-146, 2018.

[98] H. Huang, P. Li, M. Zhang et al., "Graphene quantum dots for detecting monomeric amyloid peptides," Nanoscale, vol. 9, no. 16, pp. 5044-5048, 2017.

[99] N. Mansourian, M. Rahaie, and M. Hosseini, "A nanobiosensor based on fluorescent DNA-hosted silver nanocluster and HCR amplification for detection of microRNA involved in progression of multiple sclerosis," Journal of Fluorescence, vol. 27, no. 5, pp. 1679-1685, 2017.

[100] G. Zhu and H. Lee, "Electrochemical sandwich-type biosensors for $\alpha-1$ antitrypsin with carbon nanotubes and alkaline phosphatase labeled antibody-silver nanoparticles," Biosensors \& Bioelectronics, vol. 89, pp. 959-963, 2017.

[101] F. Moreira, M. Sale, and M. Di Lorenzo, "Towards timely Alzheimer diagnosis: a self-powered amperometric biosensor for the neurotransmitter acetylcholine," Biosensors \& Bioelectronics, vol. 87, pp. 607-614, 2017.

[102] E. Rama and M. C.-G. A. González-García, "Competitive electrochemical immunosensor for amyloid-beta 1-42 detection based on gold nanostructurated screen-printed carbon electrodes," Sensors and Actuators B: Chemical, vol. 201, pp. 567-571, 2014.

[103] Á. Molinero-Fernández, M. Moreno-Guzmán, M. López, and A. Escarpa, "Magnetic bead-based electrochemical immunoassays on-drop and on-chip for procalcitonin determination: disposable tools for clinical sepsis diagnosis," Biosensors, vol. 10, no. 6, p. 66, 2020.

[104] R. Saxena and S. Srivastava, "A sensitive and one-step quantification of thyroid stimulating hormone using nanobiosensor," Materials Today: Proceedings, vol. 18, pp. 1351-1357, 2019.

[105] T. Balamurugan and S. Berchmans, "Non-enzymatic detection of bilirubin based on a graphene-polystyrene sulfonate composite," RSC Advances, vol. 5, no. 62, pp. 50470-50477, 2015.

[106] N. Cady, N. Tokranova, A. Minor et al., "Multiplexed detection and quantification of human antibody response to COVID-19 infection using a plasmon enhanced biosensor platform," Biosensors \& Bioelectronics, vol. 171, article 112679, 2021.

[107] Y. Lee, J. Choi, H.-K. Han et al., "Fabrication of ultrasensitive electrochemical biosensor for dengue fever viral RNA based on CRISPR/Cpf1 reaction," Sensors and Actuators B: Chemical, vol. 326, article 128677, 2021.

[108] S. Hashemi, N. G. Golab Behbahan, S. Bahrani et al., "Ultrasensitive viral glycoprotein detection NanoSystem toward accurate tracing SARS-CoV-2 in biological/non-biological media," Biosensors \& Bioelectronics, vol. 171, article 112731, 2021.

[109] N. Kumar, S. Bhatia, A. Pateriya et al., "Label-free peptide nucleic acid biosensor for visual detection of multiple strains of influenza A virus suitable for field applications," Analytica Chimica Acta, vol. 1093, pp. 123-130, 2020.
[110] A. Versiani, E. Martins, L. Andrade et al., "Nanosensors based on LSPR are able to serologically differentiate dengue from Zika infections," Scientific Reports, vol. 10, no. 1, p. 11302, 2020.

[111] L. L. Jeningsih, A. Ulianas, L. Y. Heng et al., "Sandwich-type DNA micro-optode based on gold-latex spheres label for reflectance dengue virus detection," Sensors, vol. 20, no. 7, p. 1820,2020

[112] K. Malsagova, T. Pleshakova, R. Galiullin et al., "Highly sensitive detection of CA 125 protein with the use of an n-type nanowire biosensor," Biosensors, vol. 10, no. 12, p. 210, 2020.

[113] B. Nohwal, R. Chaudhary, and C. Pundir, "Amperometric 1lysine determination biosensor amplified with l-lysine oxidase nanoparticles and graphene oxide nanoparticles," Process Biochemistry, vol. 97, pp. 57-63, 2020.

[114] L. J-S, J. Kim, H. Shin, and D.-H. Min, "Graphene oxidebased molecular diagnostic biosensor for simultaneous detection of Zika and dengue viruses," 2D Materials, vol. 7, article 044001, 2020.

[115] T. Matsubara, M. Ujie, T. Yamamoto et al., "Avian influenza virus detection by optimized peptide termination on a borondoped diamond electrode," ACS Sensors, vol. 5, no. 2, pp. 431-439, 2020.

[116] K. Malsagova, T. Pleshakova, R. Galiullin et al., "Nanowire aptamer-sensitized biosensor chips with gas plasma-treated surface for the detection of hepatitis $\mathrm{C}$ virus core antigen," Coatings, vol. 10, no. 8, p. 753, 2020.

[117] E. Simão, D. Silva, M. Cordeiro, L. Gil, C. Andrade, and M. Oliveira, "Nanostructured impedimetric lectin-based biosensor for arboviruses detection," Talanta, vol. 208, article 120338, 2020.

[118] L. Layqah and S. Eissa, "An electrochemical immunosensor for the corona virus associated with the Middle East respiratory syndrome using an array of gold nanoparticle-modified carbon electrodes," Microchimica Acta, vol. 186, no. 4, p. 186, 2019.

[119] M. Muti, M. Muti, and A. Erdem, "Impedimetric nanobiosensor for the detection of sequence-selective DNA hybridization," The Journal of Biological Chemistry, vol. 4, no. 46, pp. 495-503, 2018.

[120] X. Peng, Y. Zhang, D. Lu, Y. Guo, and S. Guo, "Ultrathin $\mathrm{Ti}_{3} \mathrm{C}_{2}$ nanosheets based "off-on" fluorescent nanoprobe for rapid and sensitive detection of HPV infection," Sensors and Actuators B: Chemical, vol. 286, pp. 222-229, 2019.

[121] B. Babamiri, A. Salimi, and R. Hallaj, "A molecularly imprinted electrochemiluminescence sensor for ultrasensitive HIV-1 gene detection using EuS nanocrystals as luminophore," Biosensors \& Bioelectronics, vol. 117, pp. 332-339, 2018.

[122] A. Kaushik, A. Yndart, S. Kumar et al., "A sensitive electrochemical immunosensor for label-free detection of Zikavirus protein," Scientific Reports, vol. 8, no. 1, article 9700, 2018.

[123] P. Teengam, W. Siangproh, A. Tuantranont, T. Vilaivan, O. Chailapakul, and C. Henry, "Multiplex paper-based colorimetric DNA sensor using pyrrolidinyl peptide nucleic acidinduced AgNPs aggregation for detecting MERS-CoV, MTB, and HPV oligonucleotides," Analytical Chemistry, vol. 89, no. 10, pp. 5428-5435, 2017.

[124] N. Wiriyachaiporn, H. Sirikett, W. Maneeprakorn, and T. Dharakul, "Carbon nanotag based visual detection of 
influenza A virus by a lateral flow immunoassay," Microchimica Acta, vol. 184, no. 6, pp. 1827-1835, 2017.

[125] K. He, C. Chen, C. Liang et al., "Highly selective recognition and fluorescent detection of JEV via virus-imprinted magnetic silicon microspheres," Sensors and Actuators B: Chemical, vol. 233, pp. 607-614, 2016.

[126] K. Lei, C.-H. Huang, R.-L. Kuo et al., "Paper-based enzymefree immunoassay for rapid detection and subtyping of influenza A H1N1 and H3N2 viruses," Analytica Chimica Acta, vol. 883, pp. 37-44, 2015.

[127] J. Yang, Y. Xiang, C. Song et al., "Quadruple signal amplification strategy based on hybridization chain reaction and an immunoelectrode modified with graphene sheets, a hemin/ G-quadruplex DNAzyme concatamer, and alcohol dehydrogenase: ultrasensitive determination of influenza virus subtype H7N9," Microchimica Acta, vol. 182, no. 15-16, pp. 2377-2385, 2015.

[128] P. Zhang, S. Vemula, J. Zhao et al., "A highly sensitive europium nanoparticle-based immunoassay for detection of influenza A/B virus antigen in clinical specimens," Journal of Clinical Microbiology, vol. 52, no. 12, pp. 4385-4387, 2014.

[129] L.-Y. Hung, J.-C. Chang, Y.-C. Tsai et al., "Magnetic nanoparticle-based immunoassay for rapid detection of influenza infections by using an integrated microfluidic system," Nanomedicine: Nanotechnology, Biology and Medicine, vol. 10, no. 4, article 819-829, pp. 819-829, 2014.

[130] F. Shen, J. Wang, Z. Xu et al., "Rapid flu diagnosis using silicon nanowire sensor," Nano Letters, vol. 12, no. 7, pp. 37223730, 2012.

[131] J. Zhao, S. Tang, J. Storhoff et al., "Multiplexed, rapid detection of H5N1 using a PCR-free nanoparticle-based genomic microarray assay," BMC Biotechnology, vol. 10, no. 1, p. 74, 2010.

[132] N. Naderlou, M. Salouti, B. Amini et al., "Enhanced sensitivity and efficiency of detection of Staphylococcus aureus based on modified magnetic nanoparticles by photometric systems," Artificial Cells, Nanomedicine, and Biotechnology, vol. 48, no. 1, pp. 810-817, 2020.

[133] T. N. le, T. Tran, and M. Kim, "A convenient colorimetric bacteria detection method utilizing chitosan-coated magnetic nanoparticles," Nanomaterials, vol. 10, no. 1, p. 92, 2020.

[134] Q. Vu, Q. Tran, N. Vu et al., "A label-free electrochemical biosensor based on screen-printed electrodes modified with gold nanoparticles for quick detection of bacterial pathogens," Materials Today Communications, vol. 26, no. 26, article 101726, 2021.

[135] W. Zhao, Y. Xing, Y. Lin, Y. Gao, M. Wu, and J. Xu, "Monolayer graphene chemiresistive biosensor for rapid bacteria detection in a microchannel," Sensors and Actuators Reports, vol. 2, no. 1, article 100004, 2020.

[136] G. Li, Y. Wu, Y. Li et al., "Early stage detection of_Staphylococcus epidermidis_ biofilm formation using $\mathrm{MgZnO}$ dualgate TFT biosensor," Biosensors and Bioelectronics, vol. 151, article 111993, 2020.

[137] N. Trunzo and K. Hong, "Recent progress in the identification of aptamers against bacterial origins and their diagnostic applications," International Journal of Molecular Sciences, vol. 21, no. 14, p. 5074, 2020.

[138] Y. Zheng, S. Lan, W. Chen et al., "Visual sensitivity versus ecological sensitivity: An application of GIS in urban forest park planning," Urban Forestry \& Urban Greening, vol. 41, pp. 139-149, 2019.

[139] H. Peng and I. Chen, "Rapid colorimetric detection of bacterial species through the capture of gold nanoparticles by chimeric phages," ACS Nano, vol. 13, no. 2, pp. 1244-1252, 2019.

[140] J. Lee, S. Jang, J. Chung et al., "Colorimetric allergenic fungal spore detection using peptide-modified gold nanoparticles," Sensors and Actuators B: Chemical, vol. 327, article 128894, 2021.

[141] S. Sá, A. Silva Junior, R. Lima-Neto, C. Andrade, and M. Oliveira, "Lectin-based impedimetric biosensor for differentiation of pathogenic_candida_species," Talanta, vol. 220, article 121375, 2020.

[142] M. Sezgintürk, Commercial Biosensors and Their Applications: Clinical, Food, and Beyond, Elsevier, United States, 1st ed. edition, 2020.

[143] G. Dutta, "Electrochemical biosensors for rapid detection of malaria," Materials Science for Energy Technologies, vol. 3, pp. 150-158, 2020.

[144] F. Krampa, Y. Aniweh, P. Kanyong, and G. Awandare, "Recent advances in the development of biosensors for malaria diagnosis," Sensors, vol. 20, no. 3, p. 799, 2020.

[145] O. Obisesan, A. Adekunle, J. Oyekunle, T. Sabu, T. Nkambule, and B. Mamba, "Development of electrochemical nanosensor for the detection of malaria parasite in clinical samples," Frontiers in Chemistry, vol. 7, no. 89, 2019.

[146] J. Odundo, N. Noah, D. Andala, J. Kiragu, and E. Masika, "Development of an electrochemical nano-biosensor for rapid and sensitive diagnosis of bilharzia in Kenya," South African Journal of Chemistry, vol. 71, pp. 127-134, 2018.

[147] E.-H. Yoo and S.-Y. Lee, "Glucose biosensors: an overview of use in clinical practice," Sensors, vol. 10, no. 5, pp. 4558-4576, 2010.

[148] R. Ramasamy, N. Gopal, V. Kuzhandaivelu, and S. B. Murugaiyan, "Biosensors in clinical chemistry: an overview," Advanced Biomedical Research, vol. 3, no. 1, p. 67, 2014.

[149] B. Piro, G. Mattana, and V. Noël, "Recent advances in skin chemical sensors," Sensors, vol. 19, no. 20, p. 4376, 2019.

[150] B. Ribeiro, T. Cordeiro, G. R. Oliveira e Freitas, L. Ferreira, and D. Franco, "Biosensors for the detection of respiratory viruses: a review," Talanta Open, vol. 2, article 100007, no. 2, 2020.

[151] K. Salimiyan Rizi, E. Aryan, Z. Meshkat et al., "The overview and perspectives of biosensors and Mycobacterium tuberculosis: a systematic review," Journal of Cellular Physiology, vol. 236, no. 3, pp. 1730-1750, 2021.

[152] A. Turner, "Biosensors: sense and sensibility," Chemical Society Reviews, vol. 42, no. 8, pp. 3184-3196, 2013.

[153] G.-P. Nikoleli, S. Karapetis, S. Bratakou et al., "Biosensors for security and bioterrorism: definitions, history, types of agents, new trends and applications," in Biosensors for Security and Bioterrorism Applications, D. Nikolelis and G. Nikoleli, Eds., pp. 1-13, Springer Nature, 2016.

[154] J. Zhang, X. Zhang, X. Wei, Y. Xue, H. Wan, and P. Wang, "Recent advances in acoustic wave biosensors for the detection of disease-related biomarkers: a review," Analytica Chimica Acta, vol. 338321, 2021.

[155] L. Brazaca, I. Sampaio, V. Zucolotto, and B. Janegitz, "Applications of biosensors in Alzheimer's disease diagnosis," Talanta, vol. 210, article 120644, 2020. 
[156] V. Garzón, D. Pinacho, R.-H. Bustos, G. Garzón, and S. Bustamante, "Optical biosensors for therapeutic drug monitoring," Biosensors, vol. 9, no. 4, p. 132, 2019.

[157] H. Teymourian, A. Barfidokht, and J. Wang, "Electrochemical glucose sensors in diabetes management: an updated review (2010-2020)," Chemical Society Reviews, vol. 49, no. 21, pp. 7671-7709, 2020.

[158] M. Hassan, C. Vyas, B. Grieve, and P. Bartolo, "Recent advances in enzymatic and non-enzymatic electrochemical glucose sensing," Sensors, vol. 21, no. 14, p. 4672, 2021. 